Florida International University FIU Digital Commons

\title{
The Relationship Between Parental Involvement and the Persistence of First-Generation Hispanic Millennial College Students
}

Anthony Cruz

Florida International University, cruza.01@gmail.com

DOI: $10.25148 /$ etd.FI12041114

Follow this and additional works at: https://digitalcommons.fiu.edu/etd

\section{Recommended Citation}

Cruz, Anthony, "The Relationship Between Parental Involvement and the Persistence of First-Generation Hispanic Millennial College Students" (2012). FIU Electronic Theses and Dissertations. 563.

https://digitalcommons.fiu.edu/etd/563 


\section{FLORIDA INTERNATIONAL UNIVERSITY \\ Miami, Florida}

THE RELATIONSHIP BETWEEN PARENTAL INVOLVEMENT AND THE PERSISTENCE OF FIRST-GENERATION HISPANIC MILLENNIAL COLLEGE STUDENTS

A dissertation submitted in partial fulfillment of the

requirements for the degree of

DOCTOR OF EDUCATION

in

HIGHER EDUCATION

by

Anthony Cruz

2012 
To: Dean Delia C. Garcia

College of Education

This dissertation, written by Anthony Cruz, and entitled The Relationship between Parental Involvement and the Persistence of First-Generation Hispanic Millennial College Students, having been approved in respect to style and intellectual content, is referred to you for judgment.

We have read this dissertation and recommend that it be approved.

Glenda Musoba

Lisa Stolzenberg

Marc Weinstein

Benjamin Baez, Major Professor

Date of Defense: March 20, 2012

The dissertation of Anthony Cruz is approved.

Dean Delia C. Garcia

College of Education

Dean Lakshmi N. Reddi

University Graduate School

Florida International University, 2012 
C Copyright 2012 by Anthony Cruz

All rights reserved. 


\section{DEDICATION}

I dedicate this dissertation to my parents, Antonio and Caridad Cruz. Their focus, support, and sacrifice to provide me with the best education possible served as the inspiration for the topic of this dissertation. 


\section{ACKNOWLEDGMENTS}

I wish to thank the members of my committee for their support. Dr. Musoba and Dr. Stolzenberg were particularly helpful with my quantitative methodology. Dr. Weinstein was gracious enough to join my committee when I needed him and he also provided helpful insights. I would like to thank my major professor, Dr. Ben Baez, for always keeping me grounded and focused during the last seven years.

I wish to thank Mr. Donald Letendre, my high school economics teacher, and Dr. Fran Berry, my public administration graduate school professor, for inspiring and pushing me to be the best student possible. In addition, I thank my children, James and Caroline, for showing patience even though they did not fully comprehend what I was doing. Finally, I want to thank my lovely wife, Diana, for her support, understanding, and patience throughout the entire process. Diana's support never wavered even though she shouldered the majority of the family responsibilities to allow me to fulfill my educational goals. 


\section{ABSTRACT OF THE DISSERTATION \\ THE RELATIONSHIP BETWEEN PARENTAL INVOLVEMENT AND THE PERSISTENCE OF FIRST-GENERATION HISPANIC MILLENNIAL COLLEGE STUDENTS \\ by \\ Anthony Cruz}

Florida International University, 2012

Miami, Florida

Professor Benjamin Baez, Major Professor

This dissertation was undertaken to answer the following research question: What is the relationship between parental involvement and college generation status with the persistence of Hispanic Millennial college students? Social capital theory (Coleman, 1988) was used as a theoretical framework to analyze and gain a greater understanding of the factors that correlated with the persistence of first-generation Hispanic Millennial college students. This dissertation used an ex post facto with hypothesis research design. The research hypothesis was that parental involvement would be positively related with the second-year persistence of first-generation Hispanic Millennial college students.

This dissertation used the data collected from 1179 Hispanic students who participated in the ELS: 2002 and enrolled in college. Logistic regression analysis of data from 972 of the students with completed surveys were used to examine the relationship between the dependent variable, which was student persistence to the second year, and the following independent variables: socio-economic status, family income, high school 
grade point average, gender, financial aid, highest degree ever expected, academic engagement, social engagement, college generation, and parental involvement.

This dissertation's findings show that parental involvement was not statistically associated with persistence to the second year of college, but that high school grade point average, highest degree expected, academic engagement, and the interaction between parental involvement and college generation were. While the findings do not support the hypothesis, they provide some evidence that may be supportive of the argument that recommendations that may affect degree expectations, high school GPA, and academic engagement of first generation Hispanic Millennial college students may be positively related to their college persistence. 


\section{TABLE OF CONTENTS}

CHAPTER

PAGE

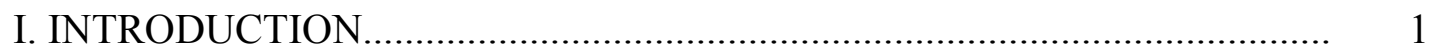

Purpose of the Study .................................................................................... 3

Theoretical Framework.................................................................................. 4

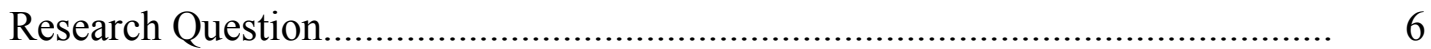

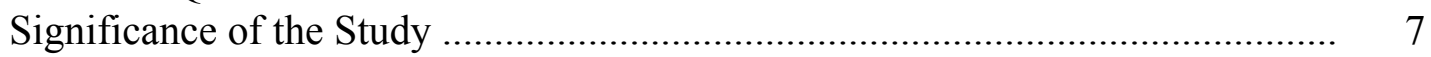

Delimitations.......................................................................................... 7

Definition of Terminology........................................................................ 8

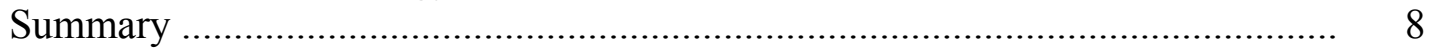

II. LITERATURE REVIEW................................................................. 10

Hispanic Demographic Trends................................................................. $\quad 10$

The Millennial Generation ...................................................................... 12

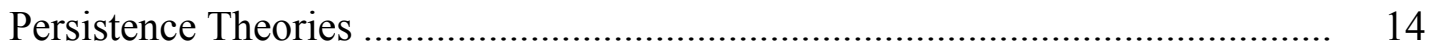

First-Generation Students ...................................................................... 15

Hispanic Student Persistence ........................................................................ 17

Parental Involvement ............................................................................ 26

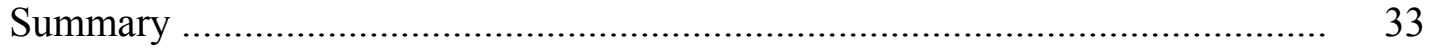

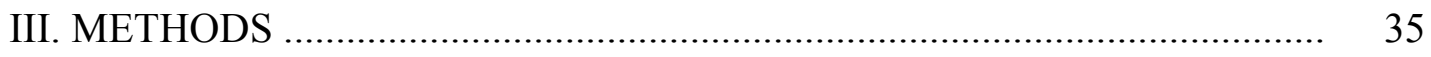

Research Design.................................................................................... 35

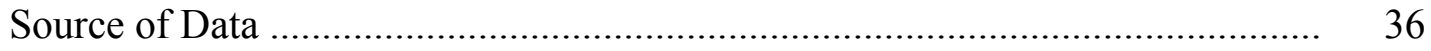

Data Collection/Instrumentation/Procedure....................................... 38

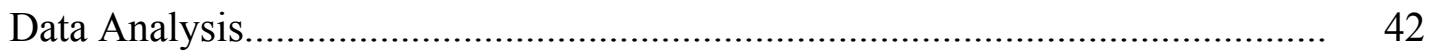

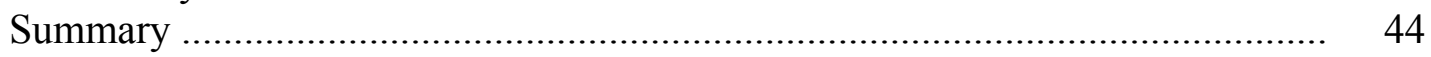

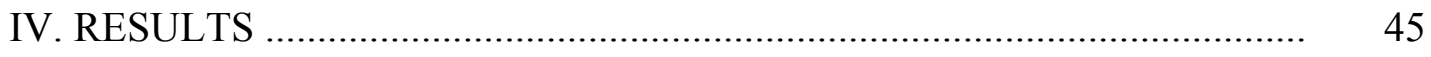

Descriptive Characteristics of the Population ................................. 45

Scale Reliability .................................................................................. 49

Research Question........................................................................ 50

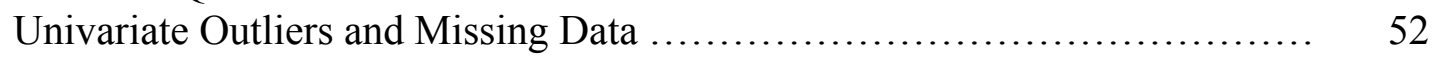

Multicollinearity ................................................... 52

Description of Logistic Regression Analysis............................. 53

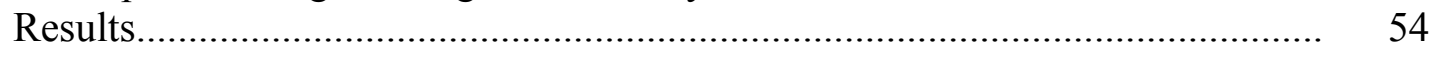

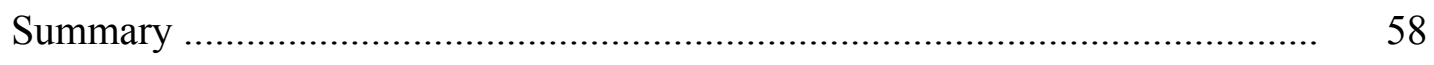

V. SUMMARY, CONCLUSIONS and RECOMMENDATIONS...................... 60

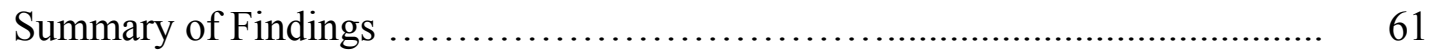

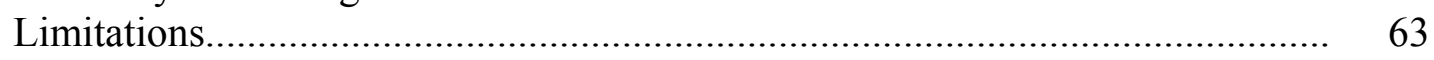

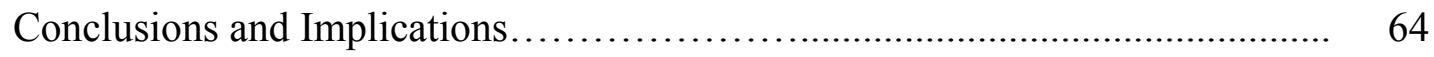

Recommendations for Research ..................................... 68

Recommendations for Practice....................................... 71 
Summary .

LIST OF REFERENCES .

VITA

84 


\section{LIST OF TABLES}

TABLE

PAGE

1. Gender of the Students in the Study....................................................... 46

2. Family Income of the Students in the Study............................................ 47

3. Socioeconomic Status Category of Students in the Study ......................... 47

4. High School Grade Point Average of Students in the Study......................... 48

5. College Generation of Students in the Study........................................... 49

6. Student Persistence to the Second Year of College..................................... 49

7. Reliability Analysis of Variables......................................................... 50

8. Model 1: Eight Variables in the Logistic Equation..................................... 54

9. Model 2: Nine Variables in the Logistic Equation..................................... 55

10. Model 3: Ten Variables in the Logistic Equation....................... 56

11. Model 4: Eleven Variables in the Logistic Equation..................... 57 


\section{Chapter I}

\section{Introduction}

The Hispanic population has grown to over fifty million, making Hispanics the largest ethnic minority group in the United States (U.S. Census Bureau, 2010). However, the growth pattern in the Hispanic population is not mirrored in higher education enrollment. While a larger proportion of Hispanics attend college than was the case 20 years ago, Hispanics continue to struggle to attend and complete college. According to the 2008 census data, only $13 \%$ of Hispanics over the age of 25 have a bachelor's degree, compared to $20 \%$ of African Americans and 33\% of non-Hispanic whites (U.S. DOE, 2009). Hispanic college students who started attending college in the year 2000 and after are part of a larger group of individuals called the Millennial generation. Millennials are arguably the most racially and ethnically diverse group of college students in United States history. The literature suggests that Millennials have a closer relationship with their parents than previous college generations because they have been more sheltered by their parents and thus have become more reliant on their parents. (DeBard, 2004). This dissertation examined the relationship between parental involvement and the persistence of first-generation Hispanic Millennial college students.

Hispanics are a heterogeneous group that represents a number of different national and ethnic origins, social classes, cultural histories, immigration and citizenship statuses, and different geographic regions of the United States. Given their separate histories and diverse experiences, each major group of Hispanics has its distinct culture. These differences make it difficult to make generalizations about the challenges that Hispanic college students face in the United States. However, there are some major 
barriers that Hispanics have in common which have an effect on their higher education attendance and persistence (Hernandez \& Lopez, 2004).

Rodriguez, Guido-DiBrito, Torres, and Talbot (2000) placed these barriers in two categories: those that exist prior to entering college and those confronted upon enrollment. Prior to entering college, many Hispanics have to deal with the disadvantages associated with low socioeconomic status and the effects of cultural stereotyping. Rodriguez et al. argue that "twenty-seven percent of Hispanic families live below the poverty level, as compared to ten-percent of non-Hispanics"(p. 514). One of the many consequences of being poor is attending segregated, poorly financed schools that can lead to low achievement and high dropout rates. In addition, many Hispanics have been affected by damaging stereotypes that have portrayed Hispanics as undisciplined, fatalistic, and irrational (Rodriguez et al., 2000). With regard to barriers while in college, Rodriguez et al. found that many Hispanics have to confront being academically underprepared and deal with the stress factors related to their finances. A disproportionate number of Hispanic college students lack the adequate high school college-preparation courses to succeed in college. Financial concerns are also a source of stress for Hispanic students because they are uncertain about receiving financial aid, they may lack the money to pay bills, and they worry about the potential debt incurred by student loans (Rodriguez et al., 2000).

While the academic preparation and financial barriers faced by Hispanic college students are formidable, the research indicates that one of the most important predictors of college persistence is the parents' educational level. Tinto has identified "anticipatory socialization" as an aid to student persistence in college (Tinto, 1987, p. 97). 
"Anticipatory socialization" means that parents with college experience are more able to assist their children with navigating the college experience. They already know basic information like how to select and register for the appropriate classes and how to avoid poor instructors. Unfortunately, most Hispanics who attend college are first-generation college students (Harrell \& Forney, 2003). First-generation college students are defined as those students whose parents did not attend college. First-generation Hispanic college students contend with the lack of academic preparation and social capital. In general, Hispanic students do not have the social capital that helps the persistence of non-firstgeneration students. Research has shown that the "amount of social capital, as well as the ability to convert social capital into educational attainment, differs by social class and race/ethnicity" (Perna, 2000, p.120).

Moreover, researchers suggest that the level of parental involvement as a form of social capital also plays an important role in college persistence. Most of the early literature focused on the importance of parental involvement in primary and secondary levels (Epstein, 1990; Hoover-Dempsey, Sandler, Green, \& Walker, 2007; McNeal, 1999). Some recent research (McCarron and Inkelas 2006; Perna, 2005) indicates that parental involvement can also have positive effects on higher education persistence and retention. The main weakness with these studies is that they have used data that are over 10 years old and have not the captured the thoughts and opinions of Millennials.

\section{Purpose of the Study}

The problem addressed in this dissertation is that Hispanic college students, especially those who are first-generation, are not succeeding in college because of the lack of academic preparation, financial resources, and social capital. The resolution to 
this problem is an urgent matter, as the Hispanic population continues to increase rapidly and fewer Hispanics are obtaining the necessary educational levels to be competitive in an ever-changing economy. Furthermore, this dissertation intended to build on the previous research on parental involvement and its effect on Hispanic student retention, with particular attention to the under-studied Hispanic Millennials (Perna \& Titus, 2005; Sciarra \& Whitson, 2007). Therefore, the purpose of this dissertation was to examine the relationship between parental involvement and the retention of first-generation Hispanic Millennial college students.

\section{Theoretical Framework}

This dissertation used social capital theory as a theoretical framework for analyzing and gaining a greater understanding of the factors that contribute to the persistence of first-generation Hispanic college Millennial students. This dissertation used the definition of social capital developed by James Coleman. According to Coleman (1988), social capital is anything that facilitates individual or collective action, generated by networks of relationships, reciprocity, trust, and social norms. Coleman's definition of social capital is the theoretical framework for this dissertation because Coleman was one of the first researchers in the United States to recognize parental involvement as a form of social capital for educational attainment. Social capital "is cumulative, possesses the capacity to reproduce profits or benefits in the social world, is convertible into tangible resources or other forms of capital, and possesses the capacity to reproduce itself in identical or in an expanded form" (Stanton-Salazar, 1997, p. 8). Social capital is a resource like human and economic capital that makes it easier to achieve certain ends. 
According to Coleman (1988), one of the most important effects of social capital is its influence on the creation of human capital in the next generation:

It is of course true that children are strongly affected by the human capital possessed by their parents. But this human capital may be irrelevant to outcomes for children if parents are not an important part of their children's lives, if their human capital is employed exclusively at work or elsewhere outside the home. The social capital of the family is the relations between children and their parents. That is, if the human capital possessed by parents is not complemented by social capital embodied in family relations, it is irrelevant to the child's educational growth that the parent has a great deal, or a small amount, of human capital. (p. 110) In addition, McNeal's (1999) premise is that parental involvement is a type of social capital that needs to be included in the analysis of educational outcomes. He found that parental involvement has a stronger relationship with dropping out than cognitive outcomes like achievement scores. While social capital should not be reduced simply to parental involvement, parental involvement is a more controllable and accessible measure of social capital than family structure and parental education. There are some measures of social capital that parents can change more easily than others. By the time children are teenagers, parents have much less control over whether two parents are present, the number of siblings, and their own education. Sandefur, Meier, and Campbell (2006) suggests that although it is important to understand the effects of parental education and family structure on educational attainment, it is also important to examine those aspects of families over which parents have more control. 
According to Berger (2000), college students with higher levels of social capital are more likely to persist than college students with less access to social capital. Those with college educated parents have better access to human and social capital through their family relationships, network of friends, and mentoring opportunities. Consequently, first-generation college students are more likely than their peers with higher levels of social capital to be hindered in accessing and understanding information to make decisions like which college to attend, the importance of completing a college degree, and the kinds of academic choices to make while attending college. Since firstgeneration college students are likely to enter college with less social capital than their peers, to persist first-generation students must use academic and social engagement during college in ways that may help them make up for the deficit. The disadvantages confronted by Hispanic first-generation students are further exacerbated by the fact that Hispanic students tend to come from lower socio-economic backgrounds and have fewer opportunities to access social capital (Pascarella et al., 2004).

\section{Research Question}

This dissertation attempted to answer the following research question:

What is the relationship between parental involvement and college generation status with the persistence of Hispanic Millennial college students?

For the purposes of this dissertation, the research question assumed the following variables: socio-economic status (SES), family income, high school grade point average, gender, highest degree ever expected, financial aid, social engagement, academic engagement, college generation (first/non-first generation), and parental involvement. The current research indicates that previously mentioned variables may be related to the 
retention of first-generation students (Ishitani, 2006; McCarron \& Inkelas, 2006; Pascarella \& Terenzini, 1980, 1983; Perna \&Titus, 2005; Rowan-Kenon, Bell, \& Perna, 2008; Stage, 1988; Stage \& Hossler, 1989; Trusty, 1998). The specific operationalization of the measures will be addressed later in this dissertation.

\section{Significance of the Study}

While there are many qualitative and quantitative studies that have focused on the persistence of first-generation students and Hispanic students in general (Hernandez, 2000; Pascarella, 2004; Perna, 2000; Somers \& Cofers, 2004), no studies were found on the relationship between parental involvement and the persistence of first-generation Hispanic Millennial college students. This dissertation is the first persistence study that

focused on Howe and Strauss' (2000) assertion that the relationship between parents and their Millennial college students is very strong and leads to more involvement in their educational lives. As a result, it was expected that the role that parental involvement would have in the persistence of these Millennial students would be more significant than what studies have found with previous generations.

\section{Delimitations}

This dissertation had two main delimitations. First, the data used in the dissertation were delimited only to Hispanic first-generation and non-first-generation college students. Second, the dissertation was delimited to students who started college after the year 2001. "Parental involvement" was limited to the answers provided by parents and students in the survey instruments included in the Education Longitudinal Study of 2002 (ELS:2002) that was designed by the United States Department of Education. 


\section{Definition of the Terminology}

\section{First-generation college student}

College students whose parents did not attend college (Pascarella et al., 2004).

\section{Hispanic}

Persons of Mexican-American, Chicano, Mexican, Mexicano, Puerto Rican, Cuban, Central or South American, or other Hispanic origin (United States, 2004).

\section{Millennials}

Students who were born after 1981 and began attending college in the year 2000 (DeBard, 2004).

\section{Parental Involvement}

Parents participating in wide array of school related topics as measured by the frequency of students discussing plans about going to college, how often parents helped with homework, how often they discussed school courses with parents, how often they discussed preparation for SAT/ACT with parents, grades with parents, discussed school activities with parents.

\section{Social Capital}

Anything that facilitates individual or collective action, generated by networks of relationships, reciprocity, trust, and social norms (Coleman, 1988). In this dissertation, it was measured by levels of parental involvement.

\section{Summary}

First-generation Hispanic Millennial college students are faced with several obstacles on their journey to obtain a college degree. Whiles academic preparation and financial barriers are formidable challenges for most Hispanic students, the literature 
(McCarron and Inkelas, 2006; Perna, 2005; Somers and Cofer , 2000) indicates that social capital measures such as parental education and parental involvement are critical retention factors as well. This dissertation examined the relationship between parental involvement and the persistence of first-generation Hispanic Millennial college students. The next chapter, the Literature Review, begins with an overview of Hispanic and Millennial demographic trends and includes previous literature on persistence theories, the characteristics and experiences of first-generation students, Hispanic student persistence studies, and the role of parental involvement as a measure of social capital. 


\section{Chapter II}

\section{Literature Review}

This chapter reviews the literature on several topics that are related to the question being addressed by this dissertation. First, this review will address Hispanic demographic data in the United States and the trends in Hispanic student college attendance and completion. Second, this review will also address the Millennial generation and what makes Millennials different from previous generations. Third, this review will provide an overview of persistence theories and includes previous literature on the characteristics and experiences of first-generation students. Fourth, this chapter will examine Hispanic student persistence studies that focus on the importance of social capital and social networks. Fifth, literature on the role of parental involvement as a measure of social capital and its impact on student retention will be reviewed.

\section{Hispanic Demographic Trends}

The Hispanic population in the United States has been grown rapidly and the academic success of Hispanic students is crucial to meeting President Obama's goal that the nation have the world's highest proportion of college graduates by 2020 (Gonzalez, 2010). From 1980 to 2005, the Hispanic population grew 192\%, from 14.6 million to 42.7 million (National Center for Education Statistics, 2007, p.6). Hispanics themselves say a college education is important. Nearly nine-in-ten Hispanics agree that a college degree is important for getting ahead in life. Young Hispanics are more likely than all young people to agree that a college degree is important for getting ahead in life than all young people ages 16 to 25 . In addition, Hispanic youth report that their parents place a great emphasis on the need to go to college. More than three-quarters of Hispanics ages 
16 to 25 say their parents think going to college is the most important thing to do after high school. Just $11 \%$ say their parents think getting a full-time job after high school is the most important thing to do (Pew Hispanic Center, 2009, p. 3).

Despite the high regard that young Hispanic people or their parents have for a college education, an educational persistence gap remains between Hispanics and nonHispanic whites. According to the Pew Hispanic Center, 33\% of Hispanics ages 18 to 24 are enrolled in school, compared with $42 \%$ of all young adults ages 18 to 24 . Moreover, a Pew Hispanic Center survey finds that there is also a gap in the educational aspirations of Hispanic young adults ages 18 to 25 and the general U.S. population of that age group. Some $48 \%$ of the former group expects to get a college degree or more, compared with $60 \%$ of the latter group (Pew Hispanic Center, 2009, p. 2).

In 2004, more postsecondary degrees were awarded to Blacks than Hispanics, despite the fact that Hispanics made up a larger percentage of the total population. In $2005,11 \%$ of all Hispanic young adults (ages 25 to 29 ) had completed at least a college degree, a lower percentage than the $28 \%$ of all young adults in the United States who had completed at least a college degree. Differences emerge in educational attainment across Hispanic subgroups. South Americans had the highest percentage of college completers, $31 \%$, followed by those of other Hispanic or Latino descent including Cubans and Spaniards with $20 \%$, Dominicans with $18 \%$, Puerto Ricans with 16\%, Mexicans with 8\%, and Central Americans with 9\% (National Center for Education Statistics, 2007, p.124). Only $51 \%$ of Hispanic students who start college complete a bachelor's degree in six years, compared to $59 \%$ of White students. Demographic trends suggest low Hispanic graduation rates will have an increasingly large effect on national educational 
attainment. According to the U.S. Census Bureau, $37 \%$ of the 44 million Hispanic U.S. residents are under the age of twenty (Gonzalez, 2010). By 2020, Hispanics will make up $22 \%$ of the nation's college-age population. It is not likely that the United States can achieve President Obama's goal of returning the United States to its historical position as the nation with the largest concentration of adults with higher education in the world without increasing Hispanic graduation rates (American Enterprise Institute, 2010, p. 3)

\section{The Millennial Generation}

Millennials are individuals who were born between 1982 and 2002. According to Howe and Strauss (2007), the Millennial generation has seven core traits: special, sheltered, confident, team-oriented, conventional, pressured, and achieving. Millennials expect to be kept safe. From school uniforms, to identity cards, to metal detectors at school, Millennials have grown up with a premium on security, and they support for harsh punishments for those who misbehave. Most Millennials are confident about their financial future, but they also place importance on the concept of creating a balance between being financially successful and making a contribution to society. Moreover, Millennials have combined their team-oriented approach with advances in technology to increase the levels of interconnection among Millennials who are less interested in the anonymous freedom of the electronic social networking than its potential to maintain their peer networks. The conventionality of the Millennials seems to stem from their general sense that rules and standards can make life easier. This generation feels loved by their parents, and perceives a diminished generation gap - their parents are in touch with their lives and it is easier for them to talk with their parents about sex, drugs and alcohol than it was for previous generations. The pressure to succeed has led to an emphasis on 
planning, and time management. Millennials have shown a great propensity to achieve. With achievement test scores at an all-time high, and strong extra-curricular programs, today's teens not only are successful, they know they are successful (Howe and Strauss, 2007).

The Millennial generation is the largest and the most diverse generation in United States history (Coomes \& DeBard, 2004). Millennials are an educationally ambitious generation, with more than three out of four college freshmen projecting they will earn a graduate degree (Sax, 2003). As the largest generation in our nation's history, the Millennial generation holds important implications for how colleges develop programs and policies during the initial decades of the twenty-first century. In 2002, approximately 6.9 million Millennials were enrolled in college, representing $44.2 \%$ of all students. By 2012, the number of Millennials is estimated to increase to 13.3 million, or $75 \%$ of all students (Coomes \& DeBard, 2004).

While Millennials are known as an educationally ambitious generation, their views on parents and their elders also make them distinct. According to the Pew Research Center Report on Millennials, they get along well with their parents. Millennials recall that during their teenage years of having had fewer disagreements with either parent than adults from previous generations say they had with their own parents when they were growing up. Moreover, Millennials state that they respect their elders. A majority say that the older generation is superior to the younger generation when it comes to moral values and work ethic. Also, more than six-in-ten say that families have a responsibility to have an elderly parent come live with them if that parent wants to. By contrast, fewer than four-in-ten adults ages 60 and older agree that this is a family responsibility (Pew 
Research Center, 2010). These views on parents and elders make the study of parental involvement on the persistence of Hispanic Millennials even more critical.

\section{Persistence Theories}

The issue of college student persistence has been studied extensively by educational researchers. The most often referred to theories in the literature are Tinto's Student Integration Model and Bean's Student Attrition Model. The Tinto model emphasizes the effects of congruency between student motivation and academic ability and an institution's social and academic characteristics. Moreover, the Tinto model views academic achievement as a measure of a student's degree of integration into an institution's academic and social environment (Tinto, 1987). One of the main criticisms of the Tinto model is that it may have somewhat limited use for commuter, nontraditional students, and minority students (Pascarella \& Chapman, 1983). On the other hand, Bean's model includes the impact of factors external to the institution. The Bean model sees academic achievement as a product of the academic and social experiences at the institution and of the student's external environment (Bean, 1980).

Cabrera and Castaneda (1993) combined both theories to produce an integrated model of student retention that considers factors in both models and additional ones related to support from friends and family, financial attitude, academic performance, intent to persist, and satisfaction with school experiences. According to the authors, this model has greater explanatory power than either model individually because it includes more variables that can affect persistence. Cabrera et al. (1992) suggest that researchers and higher education administrators consider "the interplay between institutional,

personal, external factors when developing and assessing programs aimed at preventing 
college attrition" (p. 161). The integrated model was one of the first models to introduce social capital elements, such as family and peer support to explain higher education persistence. Nonetheless, the three models mentioned above do not specifically address the characteristics of first-generation students.

\section{First-Generation Students}

Most first-generation college student persistence studies indicate that firstgeneration college students have a greater tendency to drop out than other students. In addition, first-generation college students are disproportionately non-white, low-income, and female (Lohfink \& Paulsen, 2005). Many studies have used precollege characteristics such as race and ethnicity (Hernandez, 2000; Ishitani, 2006; LeSureLester, 2003; Perna, 2000; Rowan-Kenon, Bell, \& Perna, 2008), socioeconomic status (McCarron \& Inkelas, 2006; Perna \& Titus, 2005; Trusty, 1998), and gender (Pascarella \& Terenzini, 1980, 1983; Stage, 1988; Stage \& Hossler, 1989) to discover factors related to college attrition. Moreover, Ishitani (2006) studied the effects of these precollege attributes of first-generation students on their attrition and degree completion behavior. The focal point of the study was to investigate the timing of events such as drop-out and graduation and the probability of these events occurring given certain student characteristics. First-generation college students were about 1.3 times more likely to leave college than were students whose parents were college educated. Other variables that were significantly associated with departure included family income and lower educational expectation. First-generation students faced the highest risk period of attrition during the second year. Hispanic students were $64 \%$ more likely to drop-out of college than White students in their second year of college. Although the effect of being 
a first-generation college student itself had a negative impact on college persistence, student persistence and timely graduation rates could change depending on other precollege characteristics. These factors have an impact on the access that first-generation college students have to the social networks that they need to be successful in college.

Pascarella et al. (2004) conducted a study of first-generation college students that followed students through their second and third years of college. The findings are consistent with the idea that family social capital plays a significant role in the choices students make about the institutions they attend and experiences they have once they are enrolled. The study demonstrated that first-generation college students who persisted in college were more resilient and did not necessarily have disadvantages in cognitive and non-cognitive outcomes.

In addition, extracurricular involvement in Pascarella et al.'s study (2004) had stronger positive effects on critical thinking, degree plans, and sense of control for firstgeneration students than for others. Ironically, first-generation college students derived greater benefits from extracurricular activities even though they are less likely to participate in these activities. Volunteer work, employment, and participation in athletics had a more negative impact on first-generation college students than on their peers whose parents had some college education. Furthermore, first-generation students tended to obtain significantly greater educational benefits from engagement in academic and classroom activities than their peers. The Pascarella et al. study was limited by the fact that it treated students as either "White" or "of color." While first-generation minority students share many of the same disadvantages, the study could have been strengthened by exploring the differences between the ethnic and racial groups. 
While first-generation college student studies have identified inequities that have led to differences between first-generation college students and others, few studies have looked at these first-generation college students beyond the simple distinction of firstgeneration status. Lee et al. (2004) conducted a study to determine how student characteristics of first-generation college students varied across different levels of parental education. The study used educational categories such as junior high school, high school, community college, four year college, and graduate school. The findings demonstrate that the student views and experiences are different within the firstgeneration group in several ways. First, among the racial and ethnic groups, the Hispanic students tend to have less educated parents. Second, believing that the difficulty they encounter is due to their race is a trait that is more common among students with parents who have less than a high school education than for students' parents with a high school education (Lee et al., 2004).

\section{Hispanic Student Persistence}

As the literature indicates (Hernandez, 2000; Ishitani, 2006; LeSure-Lester, 2003; Perna 2000), race and ethnicity are significant pre-college factors that affect student persistence. For the purpose of this study, it is critical to examine the literature on Hispanic student persistence that emphasizes the importance of social capital and its relationship to Hispanic student persistence.

LeSure-Lester (2003) conducted a study to examine the coping styles that Hispanic students use to manage stress encountered in college and determine whether these coping styles influenced the college persistence decisions of Hispanic students. The study consisted of 111 Hispanic students of which 27 were first-generation students and 
39 were non-first-generation students. The study was delimited to a sample of students who commuted to college. Two instruments were used to collect data from the students. First, persistence was assessed by the Persistence/Voluntary Dropout Decisions scale. It is a self-reported, 30 -item questionnaire consisting of five independent subscales. This scale has been reported to be a valid measure for the Hispanic college population (Gloria, 1993). The coping styles were measured by the trait-like version of the COPE Inventory. It is a widely used theory-based, 56-item questionnaire that is recognized as a stable measure of coping styles. This instrument has reported test-retest reliability coefficients of .45. The coping tendencies assessed included active coping, planning, suppression of competing activities, and seeking of social support for emotional reasons (LeSure-Lester, 2003).

Regression analysis in LeSure-Lester's study was conducted demonstrated that coping styles had a significant impact on the college persistence decisions of the Hispanic students in the study. College persistence decisions were positively associated with the following coping strategies: active coping, planning, and positive reinterpretation and growth. College persistence decisions were the most negatively predicted by the coping styles of denial and alcohol-drug disengagement. Moreover, a series of one-way analysis of variance were conducted using the total persistence score and the total coping scale scores. No significant gender differences were found in college persistence decisions. Results indicated that religion was the only coping strategy that was significantly different for males and females.

The study's delimitation of only using commuter students makes it difficult to generalize the findings to Hispanic students who live on campus at other institutions. 
Furthermore, a major flaw with the LeSure-Lester study is that the findings are based on self-reported measures and may not reflect the actual measures of college persistence. In addition, although first-generation Hispanic students are identified in the study, the analysis does not include the differences between the coping styles of first-generation and non-first generation Hispanic students. It would be important to find out if non-firstgeneration students possess more sophisticated or advanced coping strategies because of the influence of their college educated parents.

Furthermore, Longerbeam, Sedlacek, and Alatorre (2004) conducted a study to find out if there were significant differences in the perception of the causes of departure between Hispanic and non-Hispanic students. They administered an online questionnaire consisting of 110 questions to all entering freshmen who attended orientation at the institution in the study. The items on the questionnaire covered student perceptions, attitudes, expectations, and interests. Test-retest reliability of responses to the instrument was estimated at .84, using a pilot study of thirty questions. The survey used a Likert-type scale ranging from 1 strongly agree to 5 strongly disagree. The $\mathrm{N}$ was 2,991 students. Fifty-two percent of the respondents were men. About a quarter of the students were firstgeneration college students. Six percent of the respondents identified themselves as Hispanic/Latino. A total of 175 Hispanic/Latino students completed the survey.

Longerbeam et al. used MANOVA and chi-square statistics to analyze the survey data and found significant differences between Hispanic and non-Hispanic students regarding their attitudes towards diversity. Hispanics surveyed were in greater agreement that they had a close friend not of their own ethnicity and that they were looking forward to meeting students different from them at the university. In contrast, non-Hispanic 
students were more likely to agree that most of their friends were of their own ethnicity and were in higher agreement with feeling irritated by people of a different ethnicity or race. In addition, Hispanic students were more likely to believe that they would leave school because of lack of money and a perceived lack of ability. The findings of this study are consistent with other research that has found that lack of finances, academic stressors, and family obligations contribute to Hispanic student stress.

Hernandez (2000) conducted a qualitative study to explore how the experiences and environmental factors of ten Hispanic college students contributed to their persistence. The primary method for data collection was a series of in-depth interviews and focus groups conducted at a large public research university. Maximum variation sampling was used to select participants who had diverse backgrounds and experiences. Participants were identified through a list of graduating Hispanic students from the registrar's office, an announcement placed in the student union inviting Hispanic students to participate, and referrals from faculty and staff. The participants ranged in age from 22 to 25 and included five men and five women. Four of the participants were recent graduates and six were seniors scheduled to graduate in the semester in which the interviews were conducted. Six were born in the continental United States and the remaining four were from El Salvador, Peru, Puerto Rico, and Colombia.

The interview process was divided into three phases. During phase one, a set of open ended questions were asked to obtain general information and establish rapport. Phase two consisted of a focused exploration that allowed for detailed follow-up questions to data acquired during phase one. Finally, during phase three, the participants were invited to participate in two focus group activities to discuss emerging themes and 
provide feedback on the findings. This study used 10 individual participants and two follow-up focus groups. Furthermore, member checking occurred after each interview and after the last focus group session.

The data analysis in Hernandez's study produced several major categories or themes. All the participants expressed a positive outlook and belief that they had the potential to succeed in college. In addition, they all discussed the important role their families had on their persistence. Their families and friends were a source of both encouragement and pressure. They knew how important it was for their families and friends to see them succeed. They also mentioned the positive impact that faculty members, counselors, or advisors had on their college experience. All of the participants discussed the impact of being involved in co-curricular activities and finding other Hispanics on campus. These activities and relationships with other Hispanics on campus helped them cope with the new college environment. Hernandez found that the participants in this study did not generalize negative encounters within the environment to their overall university experience. They isolated any negative incidents and did not allow them to shape negatively their degree of satisfaction with the overall university experience. Hernandez's study reaffirms the importance of the social networks created by family, friends, faculty members, and advisors. Students rely on these social networks as they adjust to their new surroundings.

Zurita (2004) conducted a qualitative study that examined the experiences of 10 Hispanic undergraduate students. The 10 students selected were the only students to respond to the researchers requests for interviews. The participants were all recipients of the University Scholars Program (USP). The USP is scholarship program based on merit 
criteria rather than financial need. Five persisted through graduation and five did not persist and dropped out. The data were collected using one-time, semi-structured, inperson interviews with the participants. The interviews were conducted to give the students the opportunity to tell their own stories. Interviews were "divided into five major areas: differences between students' home and school cultures, financial issues, academic issues, institutional issues, and personal issues" (p. 306). The interviews were all tape recorded and lasted approximately 60-75 minutes in length. The interviews were conducted on campus and at the homes of the students.

Zurita found several similarities between those students who persisted and those who did not. First, most of them came from homes with two parents who were laborers. Second, they did not have the financial concerns of non-first-generation Hispanic students because they had received a scholarship. Third, nine out of ten of the students did not have parents who went to college. Furthermore, only one student had a sibling who had gone to college. Finally, the majority of the students did not feel that they had the support of their parents. Academic difficulties were the most significant difference between the two groups. Four of the five students who did not persist were dismissed by the university for a having a low grade point average. The findings also indicate that all the students who did not persist came from segregated high schools where they were the majority. They found themselves isolated and disengaged from the dominant White culture of the university. Zurita suggests that creating diversity on campus cannot stop with the recruitment of Hispanic students. There has to be a commitment to provide students with the necessary social networks and support services to retain them. 
Perna (2000) conducted a quantitative study to determine whether including social capital measures helps explain the college enrollment decisions of African American, Hispanic, and White students. Data from the third follow-up to the National Educational Longitudinal Study (NELS) were used to examine the research question. The NELS is sponsored by the National Center for Education Statistics. The NELS data used in the study were from a cohort of students that had graduated from high school 2 years prior. The adjusted weighted sample used in the study was 11,933 students. Descriptive and logistic regression analyses were used to determine how social capital variables affect college enrollment decisions. Perna used independent social capital variables, such as high school quality, high school desegregation, student expectations of educational attainment, parental encouragement, peer encouragement, and student interaction with teachers and counselors. Chi square and one-way ANOVA were used to identify differences between African-American, Hispanic, and White students. Logistic regression was used to isolate the effects of the independent variables on the dependent variable of college enrollment.

The descriptive statistics in Perna's study indicate that the percentage of 1992 high school graduates attending four-year colleges and universities in the Fall after high school graduation were $42 \%$ for Whites, $35 \%$ for African Americans, and $26 \%$ for Hispanics. The study found that on average, African American and Hispanic students' parents have lower levels of education than White students' parents, and parental involvement was lower for Hispanics than for the other two groups. Moreover, four conclusions can be drawn from this study. First, four-year college enrollment rates are comparable for Hispanic and Whites after controlling for differences in costs, benefits, 
ability, and social capital. Second, the results indicate that social capital is as important as academic ability for African-Americans and Hispanics. Third, academic ability is also an important predictor of enrollment. Finally, the results indicate that financial aid alone is not sufficient to increase college enrollment.

The study was limited by the variables available in the NELS database as well as by missing data. Missing data were replaced by using the average value for students of the same racial and ethnic group. Moreover, the study focused on enrollment decisions rather than student persistence. This study can serve as a launching pad for further social capital quantitative research that focuses on student persistence.

Moreover, Saunders and Serna (2004) explored the long-term effects of the Futures Project, a college access program, by examining how a group of ten firstgeneration Hispanic students made it from high school through college while maintaining the ability to access and use academic and social support mechanisms. The study was composed of both quantitative data detailing course taking patterns and grades and qualitative data detailing their college experiences. Interviews and focus groups were used to understand student goals and challenges.

Saunders and Serna used a social capital theory lens to analyze the data that were collected from the 10 Hispanic students that participated in the study. The researchers found that the behavior of most of the first-generation Hispanic students in the study fell into three categories. Six students were proficient at reconfiguring social networks and establishing new networks to ensure their academic success. Three students had the ability to maintain old relationships and networks, but could not establish new networks. 
One student was unable to maintain old networks or create new ones (Saunders \& Serna, 2004).

According to social capital theory, the ideal would be to continue with the old social networks and form new networks as well. The findings of Saunders and Serna's study justify the assumption made by proponents of social capital theory. Students in the first two categories did well academically. The mean grade point average of the students in the first category was a 2.84 , while the students in the second category had a mean grade point average of 2.59 . The one student in the third category had a grade point average of 2.18. Furthermore, the students in the first category persisted and demonstrated more comfort and confidence in their college environment without the assistance from the Project, while students in the second category continued to rely more heavily on assistance from the Project. The findings of the study suggest that intervention programs like the Futures Project have to go beyond academic preparation and to teach first-generation Hispanic students the importance of maintaining and creating new social networks.

These aforementioned studies indicate that advanced coping strategies and social networks created by family, friends and others help Hispanic college students adjust to their new college environment and have a significant impact on Hispanic student persistence (Hernandez, 2000; LeSure-Lester, 2003; Longerbeam, Serlacek, \& Alatorre, 2004; Zurita, 2004). In addition, college student proficiency at reconfiguring and maintaining social networks and establishing new ones ensures student persistence as well (Saunders \& Serna, 2004). Finally, social capital factors are as important as academic ability for Hispanic student college enrollment (Perna, 2000). 


\section{Parental Involvement}

The literature on parental involvement, support, and influence has primarily concentrated on the research at the primary and secondary levels. Much of this literature has focused specifically on the impact of parental involvement on student achievement and drop-out rates. Epstein (1990) has been one of the most prolific researchers on the subject of parental involvement at the primary and secondary levels. Epstein's research suggests that parent involvement in reading, math, and science increases student skills and positive attitudes in those subjects. Furthermore, appropriate parental involvement practices have shown to increase positive student outcomes throughout children's schooling, including the high school years. The parent's interpersonal relationships with their children and teachers emerge as the driving force behind their involvement in children's education (see also Green et al., 2007).

Coleman (1988) was the first of the social capital theorists to make the connection between parental influence and involvement as a form of social capital and educational outcomes. He used a variety of parent related social capital variables to study the dropout rate of public high school students. The variables included mother's expectations of child's educational attainment, frequency of discussions with parents about personal matters, and presence of both parents in the household. When controlling for family financial resources, Coleman found that the percentage of students who dropped out was higher for students who came from families where the expectations were low, where there were fewer parent-child discussions, and in single parent homes. The study suggests that social capital in the family is a resource for education that is just as crucial as financial capital. Furthermore, McNeal (1999) confirmed Coleman's findings that after 
controlling for socio-economic related variables, the positive effects of parental involvement on reducing the likelihood of high school dropout are significant.

Bank, Slavings, and Biddle (1990) were some of the first researchers to provide empirical evidence on the effect of peer, faculty, and parental influences on higher education persistence. Specifically, the previous research on parental influence measured the impact of parental social status characteristics, such as parental education, occupation, and income, rather than the amount of contact students have with their parents and the students' satisfaction with those contacts.

Their study used data taken from a longitudinal study of freshmen at a large, Midwestern, state university. The sample was 1,200 and closely matched the freshmen class from which it was drawn. The participants were monitored for three semesters. Of the students who participated in the first semester, $51 \%$ were male and $92 \%$ were White. The participants were asked to complete a questionnaire and to give permission to access their student records. Four-stage regression analysis was conducted to analyze data for each semester. The results indicated that parents did tend to serve as positive role models for their children. Parental influence had significant effects only during the first semester of college.

Kim and Schneider (2005) examined the effects of the parental support in student transitions to selective colleges. They specifically used social capital theory and focused on the concept of intergenerational alignment between parents' and students' ambition and action towards college admissions. They hypothesized that students who had aligned ambitions with their parents had a greater chance of attending a four-year versus a twoyear college. Furthermore, they also hypothesized that those students whose parents had 
taken aligned actions for their educational success had a greater chance of attending a selective four year college.

The data for Kim and Schneider's study were taken from the National Education Longitudinal Study of 1988-1994. Choice of postsecondary institution and selectivity of college attended were the two dependent variables used to examine the hypotheses. The independent variables included aligned ambition, defined as the agreement between the students' educational aspiration in tenth grade, and parents' expectations for their child's' educational attainment. Aligned actions by parents were also used as independent predictor variables. These aligned actions were defined as parent participation in school programs about college opportunities and the number of college visits with their children. A multinomial logistic regression model was used in the study.

Compared with students who were not in college, students enrolled in 2 or 4 year colleges had fewer siblings and more frequent discussions with their parents about academic issues. The study also indicated that parent participation with college planning and financial programs significantly improved the odds of students enrolling in a fouryear versus a two-year college. This finding confirms previous research that suggests that a good social relationship between a parent and their child is important in expanding the resources needed for students to secure better higher education opportunities (see Stanton-Salazar, 1997). Moreover, in Kim and Schneider's study, aligned ambition was a positive and significant predictor of college selectivity, and aligned actions by parents also had a significant effect on college selectivity. Parents' participation in postsecondary education guidance programs was the only social capital variable that had a significant effect on college selectivity for minority students in the study. Therefore, for minority 
and lower income families the school's capacity for proving support is crucial because those families usually have fewer resources to choose from.

Perna and Titus (2005) have examined the ways in which parental involvement is related to college enrollment. Their study created a conceptual model for understanding the relationship between parental involvement, as a form of social capital, and college enrollment. They used data from the second and third follow-ups to the National Educational Longitudinal Study (NELS). The sample was composed of 9,810 high school graduates from 1,006 high schools. The dependent variable, college enrollment, was measured in the Fall after the student's scheduled high school graduation. The independent variables included racial/ethnic groups, family income, academic preparation, parent's education, and parental involvement.

The multilevel multinomial analyses showed that student-level measures of parental involvement were related to the odds of enrolling in a 2-year or 4-year college in the fall after graduation from high school even after controlling for race/ethnicity, sex, and measures of financial capital. Furthermore, the statistically significant odds-ratios demonstrated that the odds of enrolling in college relative to not enrolling increased with the frequency with which the parent discussed with the student education-related topics, contacted the school to volunteer, and initiated contact with the school about academics. The study also revealed that after controlling for various school- and student-related variables, African Americans and Hispanics had higher odds of enrolling in a 4-year college than Whites.

The findings of this study support Coleman (1988) and Yan's (1999) conceptualization of parental involvement as a form of social capital that promotes 
college enrollment. Both the levels of parental involvement for an individual student and the volume of social capital that are available through social networks are related to the likelihood that a student will enroll in college. The results also provide support for the role of programs that are designed to increase the college enrollment of Hispanic and African Americans. While the study confirms the value of parental involvement in college enrollment, it does not indicate whether this parental involvement has a positive impact on the persistence of Hispanic college students. The social capital effect of parental involvement may wear off as students mature and separate from their parents and progress through their college careers.

McCarron and Inkelas (2006) used data from the 1988-2000 National Educational Longitudinal Study (NELS) to conduct a study whose purpose was to determine if parental involvement had a significant influence on the educational aspirations and attainment of first-generation college students as compared to the educational aspirations and attainment of non-first-generation college students. Several NELS: 88/2000 survey items were used to operationalize variables such as first-generation student status, gender, race/ethnicity, socio-economic status, parental involvement, educational aspirations, and educational attainment. Results of the multiple regression analysis for non-firstgeneration students show that parental involvement as clearly the best predictor of educational attainment. For first-generation students, however, results show that parental involvement was not the main predictor and perceptions of the importance of grades was the main predictor. For both groups, parental involvement was quite strong in explaining variance and supports prior research on the importance of parental involvement. Consistent with previous studies, Hispanic students in the study reported the lowest 
percentages in all the degree completion categories in the survey (McCarron and Inkelas, 2006). The results may have been different if parental involvement would have been operationalized using other factors. The study focused on home-based involvement and did not examine school-based involvement such as parents taking an active role in interacting with teachers and counselors.

In addition, Sciarra and Whitson (2007) conducted the most recent study on the importance of parental involvement in the postsecondary educational attainment of Hispanic students. The purpose of the study was to determine the factors that distinguish the number of Hispanic students who complete a bachelor's degree from those Hispanic students who do not complete their degrees. The researchers used the data from the 19882000 National Educational Longitudinal Study (NELS). The sample consisted of 866 Hispanic students who by the year 2000 had attended a postsecondary institution. Males were $45 \%$ of the sample and females $55 \%$. In terms of ethnicity, $62 \%$ identified themselves as Mexican or Chicano, $5 \%$ as Cuban, $9 \%$ as Puerto Rican, and $23 \%$ as other Hispanic. The majority of the students were born in the United States.

The independent variables included socio-economic status, parental support, teacher support, and psychological variables, such as locus of control and self-esteem. The dependent variable was the post-secondary education status. The post-secondary status was a categorical variable with four levels: no degree, certificate, associate's degree, and bachelor's degree or higher. A multinomial logistic regression was used to model the relationship between the categorical dependent variable with more than two possible values and a set of seven independent variables. 
The model significantly predicted Hispanic student postsecondary education attainment. Locus of control and gender were significant in differentiating between students with a certificate and those with no degree. Parental support, teacher support, and locus of control were significant predicators for those students who received an associate's degree. Socioeconomic status, parent support, math ability, locus of control, gender, and language differentiated between the students who had a bachelor's degree and higher and those who had no degree. Parental support was a very significant factor for the attainment of the associate's degree and bachelor's degree or higher. Six of the 11 items used in the parent support variable dealt with communication between the students and their parents with regard to school-related matters. The results of the study suggest that communication as a part of overall parent support enhances postsecondary educational attainment. The study also revealed that students coming from predominately Spanish speaking families had a slightly higher chance of completing a bachelor's degree.

The Sciarra and Whitson study did not differentiate parental support in terms of socioeconomic status or family composition. Is parental support greater in families with higher incomes or with two parents versus a single parent? Moreover, further research has to be done on the reasons why students who come from predominately Spanishspeaking families may have greater success. Do these families provide more support to their children?

The most significant gap in the parental involvement literature is found with regard to data from students who started college after the year 2000. These students, also known as Millennials, have their own unique characteristics and values that are 
somewhat different from students from previous college generations (DeBard, 2004). One of these characteristics is that they have been more sheltered by their parents and therefore have become more reliant on their parents than previous college generations (DeBard, 2004). Furthermore, there is a lack of research on the persistence of Hispanic Millennial college students. Therefore, a study to examine the relationship between parental involvement and the persistence of first-generation Millennial Hispanic students is important not only because of the dearth of research on the topic but also because of the need to understand a population that is increasingly growing in the United States.

\section{Summary}

The Hispanic population in the United States continues to increase at a rapid pace, while Hispanic student college attendance and completion rates are alarmingly low. Most Hispanic college students face financial and academic obstacles as well as disadvantages related to being the first person in their family to attend college. The disadvantages of being a first-generation student include the lack of social capital needed to be successful in college. The literature indicates that parental involvement can be used as a measure of social capital and that parental involvement has an impact on student retention. These previous retention studies have not addressed those Hispanic firstgeneration students who have started college since 2000. The Millennial generation is unique from previous generations because of their educational ambition and their views on parents and their role in their lives. The next chapter, Methods, provides an overview of the quantitative methods that were used to conduct this dissertation. The research design and the rationale for using quantitative research will be addressed. The chapter 
will also include the source of the data, a detailed description of the instrumentation, procedure, and conclude with the data analysis techniques. 


\section{Chapter III}

\section{Methods}

This chapter provides an overview of the quantitative methods used to perform this dissertation. The research design and the rationale for quantitative research will be addressed. The chapter will also include the source of the data, a detailed description of the instrumentation and procedure, and it will conclude with the data analysis techniques. This dissertation was undertaken to answer the following question: What is the relationship between parental involvement and college generation status with the persistence of Hispanic Millennial college students?

\section{Research Design}

An ex post facto analysis was used for this dissertation because the researcher could not control the independent variables by manipulation or by randomization. The analysis began with subjects, Hispanic Millennial students, who differed on a dependent variable, persistence to their second year of college, and tried to determine variables related to the difference (Ary, Jacobs, and Razavieh, 2002). There are "three types of ex post facto research: those without a hypothesis, those with a hypothesis, and those with a hypothesis and tests of alternative hypotheses" (Newman \& Newman, 1994, p. 116). This dissertation used the ex post facto research design with a hypothesis. The research hypothesis was that parental involvement would be positively related with the secondyear persistence of first-generation Hispanic Millennial college students.

Previous quantitative first-generation and parental involvement studies have focused on persistence and student enrollment decisions of students who started college before the year 2000 (Longerbeam, Sedlacek, \& Alatorre, 2004; McCarron and Inkelas, 
2006; Perna, 2000; Perna and Titus, 2005; Sciarra and Whitson, 2007). This dissertation focused on Hispanic Millennial students and their persistence to the second year of college.

\section{Source of Data}

This dissertation used data collected in the Education Longitudinal Study of 2002 (ELS: 2002). The Education Longitudinal Study of 2002 (ELS:2002) was designed by the United States Department of Education specifically to monitor the transition of a national sample of young people as they progressed from $10^{\text {th }}$ grade through high school and on to postsecondary education and/or the world of work. The ELS: 2002 is a nationally representative survey of students that contains a wide array of demographic, academic, and social-capital variables that were useful for this dissertation (NCES, 2008).

The ELS: 2002 data were comprised of information collected from students, parents, teachers, and school administrators. Specifically, the sources of the information are based on personal and telephone interviews, questionnaires, and test scores. The following are the details of each data collection phase. During the base year, the baseline survey of high school sophomores was completed in the spring term 2002. As part of the base year, 17,600 sophomore high school students from about 750 public, Catholic, and other private schools were identified as potentially eligible to participate in the survey. Of those eligible students, about 15,400 were located and completed the ELS: 2002 survey (NCES, 2008). Schools were the first-stage unit of selection, with sophomores randomly selected within schools. Asian and Hispanic students were oversampled in the data. At the base year, students also completed cognitive tests in reading and mathematics. In addition, the completed survey of parents, English teachers, and mathematics teachers 
were collected along with school administrator questionnaires. The first follow-up was conducted in 2004 when the students were seniors in high school. Student questionnaires, dropout questionnaires, assessments in mathematics, and school administrator questionnaire were administered as part of the follow-up. During the second follow-up in 2006, post-high-school follow-ups by computer-assisted telephone interviews were conducted and a survey was administered 2 years after scheduled high school graduation (United States, 2004).

The data collection instruments for the Education Longitudinal Study of 2002 base year consisted of five separate questionnaires administered to students, parents, teachers and school administrators, plus two achievement tests (assessments in reading and mathematics), and a school observation form. The content specification documents drew heavily on the National Assessment of Educational Progress [NAEP] and National Education Longitudinal Study of 1988 [NELS:88], and on the Program for International Student Assessment [PISA] for the achievement tests (United States, 2004).

The development and review process for each questionnaire consisted of the following steps: (a) draft elements of the questionnaires were shared with other government agencies, policy groups, and interested parties; (b) a Technical Review Panel was created and the ELS: 2002 TRP, a specially appointed independent group of substantive, methodological, and technical experts, reviewed the questionnaires; (c) the questionnaires underwent interdivisional review at NCES; (d) the survey instruments were revised based on reviewer comments; (e) a justification was written for components of the instruments; (f) the federal Office of Management and Budget (OMB) reviewed the instruments; $(\mathrm{g})$ the questionnaires were revised based on OMB comments; and (h) 
the instruments were field tested and revised based on field test results. The field testing of school enlistment and data collection and processing procedures, questionnaires, and assessments was critical in the development of the full scale base year study.

Field test instruments were evaluated in a number of ways. For the questionnaires, field test analyses included evaluation of item non-response, examination of test-retest reliabilities, calculation of scale reliabilities, and examination of correlations between theoretically related measures. The field test reliability value for the parent interview question that asked for the parent's highest level of education was $r=.86$ and $r=.73$ for the question that asked for the highest level of education expected for their child. The field test data did not provide reliability values for parental involvement related questions answered by students or parents (United States, 2004).

\section{Data Collection/Instrumentation/Procedure}

A total of 15,400 students participated in the ELS: 2002. This dissertation however, used the data collected from the 1179 Hispanic students who participated in the ELS:2002 and enrolled in college. The Hispanic students in the database are all permanent residents or citizens of the United States. This dissertation used second-year persistence as the dependent variable. The following 10 independent variables were included in the analysis: socio-economic status (SES), family income, high school grade point average, gender, highest degree ever expected, financial aid, social engagement, academic engagement, college generation (first/non-first generation), and parental involvement. The first eight independent variables mentioned above served as control variables. Socio-economic status, financial aid, social engagement, academic engagement, and parental involvement were composite variables. A theoretical approach 
was used to select the items to construct the composite variables. ELS: 2002 survey items were utilized to operationalize the 10 independent variables.

Socio-economic status (SES) was measured by a composite variable constructed from parent questionnaire data. SES was based on five equally weighted, standardized components: father/guardian's education, mother/guardian's education, family income, father's/guardian's occupation, and mother's/guardian's occupation. Each SES component was coded in the following manner: "1" for the lowest quartile, "2" for the second quartile, "3" for the third quartile, and " 4 " for the highest quartile. Pascarella and Chapman (1983) found that a higher level of socioeconomic status was positively correlated with academic and social integration, which ultimately affected student enrollment. Family income was measured by a variable constructed from parent questionnaire data. Thirteen categories of family income were reconstructed into quartiles and coded in the following manner: " 1 " for the lowest quartile (no income to $\$ 25,000)$, "2" for the second quartile $(\$ 25,001$ to $\$ 50,000)$, “3” for the third quartile $(\$ 50,001$ to $\$ 100,000)$, and “4” for the highest quartile (\$100,001 or more). Several studies (McCarron \& Inkelas, 2006; Perna \& Titus, 2005; Trusty, 1998) have operationalized socio economic status (SES) and family income in a similar manner to this dissertation.

In addition, high school grade point average (GPA) was measured by the student grade point averages for all courses taken from the 9th through 12 th grade. The measure for GPA was coded into four values from highest, $3.51-4.0$, to lowest $0.00-0.50$. Gender of the student was measured as male or female and was taken from the student questionnaire. Males were given the value of "1" and females were given the value of 
"2". Gender has been operationalized in several previous studies (Pascarella \& Terenzini, 1980, 1983; Stage, 1988; Stage \& Hossler, 1989) to explain college attrition. Moreover, the highest degree ever expected was measured by a question that asked $10^{\text {th }}$ graders, "As things stand now, how far in school do you think you will get?" Students were asked to select one of the following: Less than high school graduation, High school graduation or GED only, Attend or complete a 2-year school course in a community or vocational school, Attend college, but not complete a 4-year degree, Graduate from college, Obtain a Master's degree or equivalent, Obtain a Ph.D., M.D., or other advanced degree. The measure for highest degree ever expected was coded into seven values from lowest being 1 for Less than high school graduation, to highest being 7 for Obtain a Ph.D., M.D., or other advanced degree. Financial aid was measured by a composite variable constructed from student questionnaire data. Financial aid was based on responses of whether the students used grants and scholarships, student loans, and/or college work study to pay for their college education. Each financial aid component was coded in the following manner: "0" for no and " 1 " for yes. Rodriguez et al. (2000) operationalized financial aid variables in a similar manner.

Academic engagement was measured by a composite variable based on survey items collected from students. The academic engagement composite variable included the following factors: talked with faculty about academic matters outside of class, met with advisor about academic plans, worked on coursework at school library, and used the web to access school library for coursework. The frequencies of these responses were coded as follows: "1" for never, "2" for sometimes, and "3" for often. Social engagement was measured by a dichotomous composite variable based on student survey items. The 
social engagement composite variable included the following factors: participated in intramural or non-varsity sports, participated in varsity or intercollegiate sports, or participated in other extracurricular activities. The responses were coded as follows: "0" for no, "2" for yes. Bean (1980) and Tinto (1987) emphasize the importance of academic and social engagement variables on student retention.

The college generation of the student was measured by a dichotomous variable based on responses from the student questionnaire. For the purposes of this dissertation, first-generation students are those whose parents have an educational level of a high school diploma or less. Non-first-generation college students are those students whose parents have had at least some college. The educational level used in the dissertation is an aggregated educational level using the parent with greater educational attainment (NCES, 2008). First-generation was coded as "0" and non-first-generation was coded as "1". Somers and Cofer (2004) operationalized college generation in a similar manner.

In this dissertation, social capital was operationalized as parental involvement. Parental involvement was measured by ELS: 2002 survey items collected from high school sophomores and their parents. Parental involvement measures based on student responses included the following factors: frequency of students discussing plans about going to college, how often parents helped with homework, how often they discussed school courses with parents, how often they discussed preparation for SAT/ACT with parents, grades with parents, discussed school activities with parents. The frequency of these responses was coded as follows: " 1 " for never, " 2 " for sometimes, and "3" for often. Parental involvement measures based on parent responses included the following factors: how often they discussed report cards will be coded as "1" for never, " 2 " for 
seldom, "3" for usually, and "4" for always, attended school activities with student was coded as "1" for never, "2 "for rarely, " 3 " for sometimes, and " 4 " for frequently, and how often a parent contacted school about the student's poor performance was coded as "1" for none, "2" for once or twice, "3" for three or four times, and "4" for more than four times. These parental involvement measures are similar to those used by McCarron and Inkelas (2006), Perna (2000, 2005), and Somers and Cofer (2000). They have recommended including measures of parental social capital in persistence studies in order to explain more of the variance in persistence rates.

\section{Data Analysis}

Statistical Package for the Social Sciences (SPSS) software was utilized to perform descriptive statistical analysis. In addition, this dissertation used logistic regression in a manner that is consistent with previous student persistence studies (Glynn, Sauer \& Miller 2003; Kim and Schneider 2005; Madgett and Bélanger 2008; Perna 2000; Stage 1988). Stage (1988) demonstrated how logistic regression could be used to test hypotheses regarding associations among background characteristics, commitment levels, institutional involvements, and persistence for male and female undergraduate university students. According to Stage (1988), results from the logistic regression, in addition to identifying significant predictors of persistence within each subgroup, may be used to calculate odds that a student with given characteristics and experiences persists.

Glynn (2003) also used logistic regression to develop a model that sought to provide information to enhance early identification of freshmen at risk of attrition. The functional form of the model represented the probability of persistence. The dichotomous dependent variable was persistence, and its value (persist or drop out) was the outcome of 
a choice process. Given the dichotomous dependent variable and the goal of maximizing predictability, the independent variables were all modeled as having direct effects in a logistic regression.

Logistic regression analysis was used in this dissertation to examine the relationship between the dependent variable, which is student persistence to the second year, and the 10 independent variables stated above. The dependent variable was dichotomous and was represented by "1" for those who persisted to their second year of college and " 0 " for those who did not persist to their second year of college. Multiple regression generally requires that the dependent variable be of interval levels, and that the distribution of errors be normally distributed. When the dependent variable, like the one used in this dissertation, is represented as a dichotomous variable, errors in prediction are not normally distributed, and the predicted values cannot be interpreted as probabilities. Therefore, it was appropriate to use a logistic regression approach under these circumstances (Hosmer \& Lemeshow, 1989). SPSS software was utilized to perform the logistic regression. The Cox and Snell R-square was used as a measure of association. Furthermore, this dissertation used a significance level of $\alpha=.05$. Four logistic regression models were used: (a) the first was a baseline model that included only the eight control variables, (b) the second model added college generation, (c) the third model added parental involvement, and (d) the fourth model included the interaction between parental involvement and college generation.

\section{Summary}

A quantitative analysis of the relationship between parental involvement and the persistence of Hispanic first-generation Millennial college students will help fill a gap in 
the literature. This dissertation will identify the factors that contribute to first-generation Hispanic student persistence and help develop effective persistence strategies. 


\section{Chapter IV}

\section{Results}

In this chapter, results of the statistical analysis that were conducted with respect to this dissertation's design and procedures are discussed. Descriptive analysis of the characteristics of the population data was conducted followed by logistic regression analysis to examine the relationship between several variables and the persistence of Hispanic Millennial college students to the second year of college. Inferential statistics were used to draw conclusions from the sample population tested.

The purpose of this quantitative dissertation was to examine the relationship between parental involvement and the persistence of first-generation Hispanic millennial college students. The research question that guided this dissertation was: What is the relationship between parental involvement and college generation status with the persistence of Hispanic Millennial college students? Therefore, parental involvement was anticipated as an important persistence factor in this dissertation. It was also anticipated that college generation status would also be a significant predictor of persistence to the second year of college.

\section{Descriptive Characteristics of the Population}

Using narrative and tables, the entire population that was part of this dissertation is described in the first section of this chapter. This descriptive information includes all students and is presented because not all students were included in the logistic regression analysis. Students who did not complete survey questions in regards to financial aid, high school grade point average, highest degree expected, and social engagement were excluded from the logistic regression analysis. The population in this dissertation 
consisted of 1179 Hispanic Millennial students who participated in the ELS: 2002 and attended college after graduating from high school.

By gender, Table 1 depicts that the study population was majority female with $n=$ $662(56.1 \%)$ and male $n=517(43.9 \%)$. While the ratio of females to males in this dissertation is similar to the national ratio of Hispanic females to Hispanic males enrolled in college, it is substantially different than the female-male ratio for all students who participated in the ELS: 2002, female 50\% and 50\% male (National Center for Education Statistics, 2007).

Table 1

Gender of the Students in the Study

\begin{tabular}{lcc}
\hline Gender & $n$ & $\%$ \\
\hline Female & 662 & 56.1 \\
Male & 517 & 43.9 \\
Total & 1179 & 100.0 \\
\hline
\end{tabular}

Table 2 depicts the family income categories used in this dissertation. The majority of students in the study had annual family incomes below $\$ 50,001$. The largest percentage (34.1\%) of students had annual family incomes in the range of $\$ 25,000$ $\$ 50,000$. The majority of all ELS: 2002 participants also had annual family incomes below $\$ 50,001$. 
Table 2

Family Income of the Students in the Study

\begin{tabular}{lcc}
\hline Family Income Category & $n$ & $\%$ \\
\hline None $-\$ 25,000$ & 339 & 28.8 \\
$\$ 25,001-\$ 50,000$ & 402 & 34.1 \\
$\$ 50,001-\$ 100,000$ & 314 & 26.6 \\
Above $\$ 100,000$ & 124 & 10.5 \\
Total & 1179 & 100.0 \\
\hline
\end{tabular}

By socioeconomic status category, Table 3 depicts that the majority of the dissertation population fell into the lowest two quartiles. The socioeconomic status variable is a composite variable based on five equally weighted components: father's education, mother's education, family income, father's occupation, and mother's occupation. The majority of all ELS: 2002 participants fell into the two lowest quartiles.

Table 3

Socioeconomic Status Category of the Students in the Study

\begin{tabular}{lcc}
\hline Socioeconomic Category & $n$ & $\%$ \\
\hline Lowest Quartile & 435 & 36.9 \\
Second Quartile & 261 & 22.1 \\
Third Quartile & 246 & 20.9 \\
Highest Quartile & 237 & 20.1 \\
Total & 1179 & 100.0 \\
\hline
\end{tabular}


Table 4 presents the students by grade point average category based on their cumulative high school grade point average when they graduated from high school. The largest group was composed of students with grade point averages between 1.51 and 2.5 based on a 4.0 scale. Eighty six students in the study did not provide grade point average information.

Table 4

High School Grade Point Average of the Students in the Study

\begin{tabular}{lcc}
\hline Grade Point Average Category & $n$ & $\%$ \\
\hline $0.00-1.50$ & 177 & 15 \\
$1.51-2.50$ & 519 & 44 \\
$2.51-3.50$ & 240 & 20.4 \\
$3.51-4.00$ & 157 & 13.3 \\
Total & 1093 & 92.7 \\
No GPA Information & 86 & 7.3 \\
Total & 1179 & 100.0 \\
\hline
\end{tabular}

Table 5 presents the students in the study by whether they were first-generation or non-first-generation college students. First-generation college students are defined as those students whose parents did not attend college. Approximately two thirds (66.3\%) of the student study population were non-first-generation students. 
Table 5

College Generation of Students in the Study

\begin{tabular}{lll}
\hline College Generation & $n$ & $\%$
\end{tabular}

First-Generation

397

33.7

Non-First Generation

782

66.3

Total

1179

100.0

Table 6 depicts that almost $75 \%$ of the students in this dissertation persisted to their second year of college. This percentage is higher than the national average for Hispanic college students persisting to their second year of college.

Table 6

Student Persistence to the Second Year of College

\begin{tabular}{lcc}
\hline Student Persistence & $n$ & $\%$ \\
\hline No & 304 & 25.8 \\
Yes & 875 & 74.2 \\
Total & 1179 & 100.0 \\
\hline
\end{tabular}

\section{Scale Reliability}

Reliability analysis allows one to study the properties of measurement scales and the items that compose the scales (Tabachnick \& Fidell, 2007). Cronbach's alpha reliability analysis procedure calculates a reliability coefficient that ranges between 0 and 1. The reliability coefficient is based on the average inter-item correlation. Scale reliability is assumed if the coefficient is $>=.70$. 
Table 7 depicts summary statistics of the reliability analyses for four independent variables used in this dissertation. Cronbach's alpha $(\alpha)$ coefficients greater than 0.60 were assumed to be reasonably reliable. Results from the analyses revealed that three constructs were sufficiently reliable. Specifically, reliability for the variable Parental Involvement was calculated at .926 for the nine items tested, Academic Engagement was .618 for four items, and Financial Aid was .933 for three items. Although Cronbach's alpha for Social Engagement was less than .60, it was not found to be statistically different from the critical value of $.70 ; p=.05$.

Table 7

Reliability Analysis of Variables

\begin{tabular}{lccc}
\hline \multicolumn{1}{c}{ Scale } & $n$ & $\begin{array}{c}\text { Cronbach's } \\
\text { Alpha }\end{array}$ & $\begin{array}{c}\text { Cronbach's Alpha Based on } \\
\text { Standardized Items }\end{array}$ \\
& & 0.926 & 0.931 \\
Parental Involvement & 9 & 0.618 & 0.628 \\
Academic Engagement & 4 & 0.595 & 0.598 \\
Social Engagement & 3 & 0.933 & 0.935 \\
Financial Aid & 3 & & \\
\hline
\end{tabular}

\section{Research Question}

What is the relationship between parental involvement and college generation status with the persistence of Hispanic Millennial college students? The research question was analyzed using logistic regression. The dependent variable was defined as a student's persistence to advance to the second year of college (Persistence) and the independent variables were socioeconomic status, family income, high school grade point average, 
gender, highest degree expected, financial aid, social engagement, academic engagement, college generation, and parental involvement. To calculate Persistence, a dichotomous variable was created by coding 0 for those who did not persist to the second year (leaverimmediate entry/no 2006 enrollment, and delayer-delayed/no 2006 enrollment) and 1 for those who did persist to the second year of college (standard enrollee, and delayerdelayed entry/enrolled in 2006). Socioeconomic status was a categorical variable and coded as lowest quartile, second quartile, third quartile, and highest quartile. Family income was a categorical variable coded as 1 for the lowest quartile (no income to $\$ 25,000), 2$ for the second quartile ( $\$ 25,001$ to $\$ 50,000), 3$ for the third quartile ( $\$ 50,001$ to $\$ 100,00)$ and 4 for the highest quartile ( $\$ 100,001$ or more). College generation was a dichotomous variable coded as 1 for first-generation (parents did not attend college) and 2 for second generation college student (parents did attend college).

Gender was a categorical variable coded 1 for male and 2 for female. Highest degree expected was a categorical variable (less than high school graduation, GED or other equivalency only, high school graduation only, attend or complete 2-year college school, attend college/4-year degree incomplete, graduate from college, obtain master's degree or equivalent, obtain $\mathrm{PhD}, \mathrm{MD}$, or other advanced degree). Grade point average (GPA) variable was created from grade point average for all courses taken in the ninth through $12^{\text {th }}$ grades, and reconstructed into quartiles. The lowest GPA quartile included 0.00 to 1.50 , the second GPA quartile included 1.51 to 2.50 , the third GPA quartile included 2.51 to 3.50, and the highest GPA quartile included 3.51 to 4.00 .

A theoretical approach was used to select the items to construct the composite variables. Academic engagement was a composite variable in that responses to scale 
items (meet with faculty, meet with advisor, coursework in school library, and use web access to school library) were summed and divided by the number of questions (4) to create a mean score. Social engagement was a composite variable in that responses to scale items (intramural sports, varsity sports, extracurricular activities) were summed and divided by the number of questions (3) to create a mean score. The financial aid variable was a composite variable in that responses to scale items (grants and scholarships, student loans, college work study) were summed and divided by the number of questions (3) to create a mean score. The parental involvement variable included nine (9) items (frequency of discussing college plans, parents help with homework, discussed courses with parents, discussed prep for SAT/ACT, discussed grades with parents, discussed school activities with parents, discussed report cards, attended activities, and contacted school about report card).

\section{Univariate Outliers and Missing Data}

A test for univariate outliers was conducted and none were found to exist within the distributions. Cases were excluded that had missing values for any of the independent variables. Thus, 1179 individuals participated in the survey and 972 complete responses from participants were entered into the logistic regression model; $n=972$.

\section{Multicollinearity}

The assumptions of multicollinearity were tested by calculating correlations between variables. Correlations between the independent variables were low. The highest correlations among the 10 variables were between socioeconomic background and college generation $(r=.638, p<.001)$, socioeconomic background and family income $(r$ $=.650, p<.001)$, highest degree expected and high school GPA $(r=.350, p<.001)$, and 
highest degree expected and the academic engagement composite $(r=.312, p<.001)$.

None of the correlations between independent variables exceeded the recommended critical limit of .70. There were no correlation results violating this assumption; therefore, the presence of multicollinearity was not assumed. In addition, variance inflation factors (VIF) were calculated and used to analyze the magnitude of multicollinearity among three or more of the independent variables. None of the variance inflation factors exceeded the recommended critical limit of 5. Given the evidence provided, assumptions associated with logistic regression were affirmed. That is, after examining the multicollinearity diagnostics and other descriptive statistics, the distributions were assumed to meet parametric assumptions.

\section{Description of Logistic Regression Analysis}

Logistic regression analysis was used to predict persistence in the second year of college. Independent variables were entered in four models: (1) SES, Family Income, High School GPA, Gender, Highest Degree Expected, Financial Aid, Academic Engagement, and Social Engagement; (2) the previously mentioned eight variables and College Generation; (3) the previously mentioned nine variables and Parental Involvement; and (4) the previously mentioned 10 variables and College Generation X Parent Involvement Interaction. Overall model fit was statistically assessed with the Likelihood Ratio $\chi^{2}$ test and the Cox-Snell- $\mathrm{R}^{2}$. Statistical improvement in model fit at each subsequent model (relative to the previous model) was assessed with the change in $\chi^{2}\left(\Delta \chi^{2}\right)$ test. Finally, the statistical significance of individual independent variables was determined. Analyses were based on 972 participants who had complete data. 


\section{Results}

In Model 1, the statistical model with the eight independent variables fit

significantly well, $\chi^{2}(\mathrm{df}=8)=144.03, p<.001$, Cox-Snell $-\mathrm{R}^{2}=.14$. As shown in Table 8, High School GPA, Highest Degree Expected, and Academic Engagement were significantly and positively associated with persistence to the second year of college.

Individuals with higher high school GPAs, higher expectations for advanced degrees, and that were more academically engaged were more likely to persistent to their second year of college.

Table 8

Model 1: Eight Variables in the Logistic Equation

\begin{tabular}{|c|c|c|c|c|c|c|c|c|}
\hline \multirow[b]{2}{*}{ Variables } & \multirow[b]{2}{*}{ B } & \multirow[b]{2}{*}{ S.E. } & \multirow[b]{2}{*}{ Wald } & \multirow[b]{2}{*}{ df } & \multirow[b]{2}{*}{ Sig. } & \multirow[b]{2}{*}{$\operatorname{Exp}(B)$} & \multicolumn{2}{|c|}{$\begin{array}{l}95 \% \text { C.I. for } \\
\text { EXP(B) }\end{array}$} \\
\hline & & & & & & & Lower & Upper \\
\hline Socio-econ & 0.154 & 0.098 & 2.491 & 1 & 0.115 & 1.167 & 0.963 & 1.413 \\
\hline $\begin{array}{l}\text { Family } \\
\text { Income }\end{array}$ & 0.176 & 0.117 & 2.276 & 1 & 0.131 & 1.192 & 0.949 & 1.499 \\
\hline GPA & $0.532 *$ & 0.109 & 24.02 & 1 & 0 & 1.702 & 1.376 & 2.105 \\
\hline Gender & -0.166 & 0.172 & 0.93 & 1 & 0.335 & 0.847 & 0.605 & 1.186 \\
\hline $\begin{array}{l}\text { Highest } \\
\text { Degree }\end{array}$ & $0.318^{*}$ & 0.062 & 26.475 & 1 & 0 & 1.375 & 1.218 & 1.552 \\
\hline Fin Aid & -0.006 & 0.009 & 0.44 & 1 & 0.507 & 0.994 & 0.976 & 1.012 \\
\hline $\begin{array}{l}\text { Acad } \\
\text { Engage }\end{array}$ & $0.6^{*}$ & 0.173 & 12.068 & 1 & 0.001 & 1.823 & 1.299 & 2.558 \\
\hline $\begin{array}{l}\text { Social } \\
\text { Engage }\end{array}$ & 0.018 & 0.055 & 0.103 & 1 & 0.748 & 1.018 & 0.914 & 1.133 \\
\hline Constant & -3.558 & 0.518 & 47.221 & 1 & 0 & 0.029 & & \\
\hline
\end{tabular}


In Model 2, while the model continued to fit well overall, $\chi^{2}(\mathrm{df}=9)=144.86, p<.001$, Cox-Snell $-\mathrm{R}^{2}=.14$, the addition of the College Generation variable did not statistical improve model fit, $\Delta \chi^{2}(\mathrm{df}=1)=0.83, p=.361$. College Generation was not statistically associated with persistence to the second year of college (see Table 9).

Table 9

Model 2: Nine Variables in the Logistic Equation

\begin{tabular}{|c|c|c|c|c|c|c|c|c|}
\hline \multirow[b]{2}{*}{ Variables } & \multirow[b]{2}{*}{ B } & \multirow[b]{2}{*}{ S.E. } & \multirow[b]{2}{*}{ Wald } & \multirow[b]{2}{*}{$\mathrm{df}$} & \multirow[b]{2}{*}{ Sig. } & \multirow[b]{2}{*}{$\operatorname{Exp}(B)$} & \multicolumn{2}{|c|}{$\begin{array}{l}\text { 95\% C.I.for } \\
\text { EXP(B) }\end{array}$} \\
\hline & & & & & & & Lower & Upper \\
\hline Socio-econ & 0.097 & 0.116 & 0.701 & 1 & 0.402 & 1.102 & 0.878 & 1.383 \\
\hline $\begin{array}{l}\text { Family } \\
\text { Income }\end{array}$ & 0.180 & 0.117 & 2.384 & 1 & 0.123 & 1.198 & 0.953 & 1.506 \\
\hline GPA & $0.536^{*}$ & 0.109 & 24.387 & 1 & 0.000 & 1.710 & 1.382 & 2.116 \\
\hline Gender & -0.173 & 0.172 & 1.012 & 1 & 0.314 & 0.841 & 0.600 & 1.178 \\
\hline $\begin{array}{l}\text { Highest } \\
\text { Degree }\end{array}$ & $0.317^{*}$ & 0.062 & 26.071 & 1 & 0.000 & 1.372 & 1.215 & 1.550 \\
\hline Fin Aid & -0.007 & 0.009 & 0.539 & 1 & 0.463 & 0.993 & 0.975 & 1.011 \\
\hline Acad Engage & $0.609 *$ & 0.173 & 12.368 & 1 & 0.000 & 1.838 & 1.309 & 2.581 \\
\hline $\begin{array}{l}\text { Social } \\
\text { Engage }\end{array}$ & 0.017 & 0.053 & 0.108 & 1 & 0.742 & 1.018 & 0.917 & 1.129 \\
\hline College Gen & 0.196 & 0.214 & 0.831 & 1 & 0.362 & 1.216 & 0.799 & 1.851 \\
\hline Constant & -3.572 & 0.518 & 47.510 & 1 & 0.000 & 0.028 & & \\
\hline
\end{tabular}

In Model 3, the overall model continued to fit well, $\chi^{2}(\mathrm{df}=10)=144.87, p<.001$, CoxSnell $-\mathrm{R}^{2}=.14$. However, the addition of the Parental Involvement predictor also did not 
statistically improve model fit, $\Delta \chi^{2}(\mathrm{df}=1)=0.00, p=.96$. Parental Involvement was not statistically associated with persistence to the second year of college (see Table 10).

Table 10

Model 3: Ten Variables in the Logistic Equation

\begin{tabular}{|c|c|c|c|c|c|c|c|c|}
\hline \multirow[b]{2}{*}{ Variables } & \multirow[b]{2}{*}{ B } & \multirow[b]{2}{*}{ S.E. } & \multirow[b]{2}{*}{ Wald } & \multirow[b]{2}{*}{ df } & \multirow[b]{2}{*}{ Sig. } & \multirow[b]{2}{*}{$\operatorname{Exp}(B)$} & \multicolumn{2}{|c|}{$\begin{array}{l}\text { 95\% C.I.for } \\
\text { EXP(B) }\end{array}$} \\
\hline & & & & & & & Lower & Upper \\
\hline Socio-econ & 0.097 & 0.116 & 0.703 & 1 & 0.402 & 1.102 & 0.878 & 1.383 \\
\hline $\begin{array}{l}\text { Family } \\
\text { Income }\end{array}$ & 0.181 & 0.117 & 2.385 & 1 & 0.122 & 1.198 & 0.953 & 1.506 \\
\hline GPA & $0.537^{*}$ & 0.11 & 23.944 & 1 & 0.000 & 1.711 & 1.380 & 2.122 \\
\hline Gender & -0.172 & 0.173 & 0.993 & 1 & 0.319 & 0.842 & 0.600 & 1.181 \\
\hline $\begin{array}{l}\text { Highest } \\
\text { Degree }\end{array}$ & $0.317^{*}$ & 0.062 & 26.052 & 1 & 0.000 & 1.372 & 1.215 & 1.550 \\
\hline Fin Aid & -0.007 & 0.009 & 0.54 & 1 & 0.462 & 0.993 & 0.975 & 1.011 \\
\hline $\begin{array}{l}\text { Acad } \\
\text { Engage }\end{array}$ & $0.61 *$ & 0.174 & 12.239 & 1 & 0.000 & 1.840 & 1.308 & 2.589 \\
\hline $\begin{array}{l}\text { Social } \\
\text { Engage }\end{array}$ & 0.018 & 0.053 & 0.109 & 1 & 0.742 & 1.018 & 0.917 & 1.129 \\
\hline $\begin{array}{l}\text { College } \\
\text { Gen }\end{array}$ & 0.196 & 0.215 & 0.833 & 1 & 0.361 & 1.217 & 0.798 & 1.856 \\
\hline Parental & -0.001 & 0.015 & 0.002 & 1 & 0.961 & 0.999 & 0.970 & 1.029 \\
\hline Constant & -3.58 & 0.539 & 44.025 & 1 & 0.000 & 0.028 & & \\
\hline
\end{tabular}

In Model 4, the overall model continued to fit well, $\chi^{2}(\mathrm{df}=11)=151.83, p<.001$, CoxSnell $-\mathrm{R}^{2}=.15$. Moreover, the addition of the College Generation X Parental 
Involvement interaction term statistically improved model fit, $\Delta \chi^{2}(\mathrm{df}=1)=6.96, p=$ .008 and was associated with persistence to the second year of college (see Table 11).

Table 11

Model 4: Eleven Variables in the Logistic Equation

\begin{tabular}{|c|c|c|c|c|c|c|c|c|}
\hline \multirow[b]{2}{*}{ Variables } & \multirow[b]{2}{*}{ B } & \multirow[b]{2}{*}{ S.E. } & \multirow[b]{2}{*}{ Wald } & \multirow[b]{2}{*}{$\mathrm{df}$} & \multirow[b]{2}{*}{ Sig. } & \multirow[b]{2}{*}{$\operatorname{Exp}(B)$} & \multicolumn{2}{|c|}{$\begin{array}{l}\text { 95\% C.I.for } \\
\text { EXP(B) }\end{array}$} \\
\hline & & & & & & & Lower & Upper \\
\hline Socio-econ & 0.102 & 0.116 & 0.77 & 1 & 0.380 & 1.107 & 0.882 & 1.389 \\
\hline $\begin{array}{l}\text { Family } \\
\text { Income }\end{array}$ & 0.188 & 0.117 & 2.577 & 1 & 0.108 & 1.207 & 0.959 & 1.518 \\
\hline GPA & $0.538^{*}$ & 0.111 & 23.635 & 1 & 0.000 & 1.712 & 1.378 & 2.127 \\
\hline Gender & -0.175 & 0.174 & 1.017 & 1 & 0.313 & 0.839 & 0.597 & 1.180 \\
\hline $\begin{array}{l}\text { Highest } \\
\text { Degree }\end{array}$ & $0.324 *$ & 0.062 & 26.962 & 1 & 0.000 & 1.383 & 1.224 & 1.563 \\
\hline Fin Aid & -0.007 & 0.009 & 0.627 & 1 & 0.428 & 0.993 & 0.975 & 1.011 \\
\hline $\begin{array}{l}\text { Acad } \\
\text { Engage }\end{array}$ & $0.632^{*}$ & 0.175 & 12.99 & 1 & 0.000 & 1.881 & 1.334 & 2.653 \\
\hline $\begin{array}{l}\text { Social } \\
\text { Engage }\end{array}$ & 0.016 & 0.057 & 0.081 & 1 & 0.775 & 1.016 & 0.910 & 1.135 \\
\hline $\begin{array}{l}\text { College } \\
\text { Gen }\end{array}$ & 0.131 & 0.22 & 0.354 & 1 & 0.552 & 1.140 & 0.741 & 1.752 \\
\hline Parental & 0.042 & 0.022 & 3.521 & 1 & 0.061 & 1.043 & 0.998 & 1.089 \\
\hline $\begin{array}{l}\text { Parental } \\
\text { colgen }\end{array}$ & $0.078^{*}$ & 0.03 & 6.798 & 1 & 0.009 & 0.925 & 0.872 & 0.981 \\
\hline Constant & -3.606 & 0.544 & 43.962 & 1 & 0.000 & 0.027 & & \\
\hline
\end{tabular}

To describe this interaction effect more completely, the follow-up testing approach of Jaccard (2001) was used. First, the relationship between College Generation 
and persistence to the second year of college was evaluated for those low in Parental Involvement (defined as one standard deviation below the mean for this variable) and high in Parental Involvement (defined as one standard deviation above the mean for this variable). Second, the relationship between Parental Involvement and persistence to the second year of college was evaluated for first-generation college students and non-first year generation college students.

For the follow-up tests evaluating the relationship between College Generation and persistence to the second year of college at low and high parental involvement, there was a statistically significant association for low Parental Involvement $(\mathrm{B}=.58, p=.027$, $\mathrm{OR}=1.79,95 \%$ OR $\mathrm{CI}=1.07-3.00)$. For those students who have low parental involvement, non-first generation college students were more likely to persist to the second year of college than first-generation college students. There was not a statistically significant association between College Generation and persistence to the second year of college for high Parental Involvement $(\mathrm{B}=-.32, p=.276, \mathrm{OR}=0.73,95 \%$ OR $\mathrm{CI}=0.41$ 1.29).

For the follow-up tests evaluating the relationship between Parental Involvement and persistence to the second year of college for values of College Generation, there was neither a statistical significant association for first-generation college students $(\mathrm{B}=.042$, $p=.061, \mathrm{OR}=1.04,95 \% \mathrm{OR} \mathrm{CI}=1.00-1.09)$ or for non-first generation college students $(\mathrm{B}=-.04, p=.079, \mathrm{OR}=0.96,95 \%$ OR $\mathrm{CI}=0.93-1.00)$.

\section{Summary}

This study was designed to determine the relationship between parental involvement and the persistence of first-generation Hispanic Millennial college students. 
Findings suggest that parental involvement was not statistically associated with persistence to the second year of college, but high school grade point average, highest degree expected, academic engagement, and the interaction between parental involvement and college generation were statistically associated with persistence to the second year of college. These findings are further elaborated in Chapter 5. Conclusions and recommendations are also discussed in Chapter 5. 


\section{Chapter V}

\section{Summary, Conclusions and Recommendations}

This dissertation was undertaken to test if some of the findings in the literature pertaining to the persistence of Hispanic college students were evident in the student population that was the focus of this dissertation: first-generation Hispanic Millennial college students.

Historically, research on parental involvement has primarily concentrated on students in elementary and high school. In the past ten years, the literature focusing on the effect of parental involvement on the college student has increased. Several studies have identified parental involvement as a form of social capital that promotes college enrollment or educational attainment (McCarron and Inkelas, 2006; Perna and Titus, 2005; Sciarra and Whitson, 2007; Yan, 1999). While previous studies have confirmed the value of parental involvement in the college enrollment decisions and educational attainment of previous college generations, what researchers have overlooked to this point is an examination of the correlation between parental involvement and the persistence of first-generation Hispanic Millennial college students.

The purpose of this quantitative dissertation was to examine the relationship between parental involvement and the persistence of first-generation Hispanic millennial college students. The research question that guided this dissertation was: What is the relationship between parental involvement and college generation status with the persistence of Hispanic Millennial college students? This question was explored using logistic regression with persistence to the second year as the dependent variable. The independent variables in this dissertation were socioeconomic status (SES), family 
income, high school grade point average (GPA), gender, highest degree expected, financial aid, social engagement, academic engagement, college generation and parental involvement. Chapter 4 provides a full account of the data and results of the dissertation. The following section provides an overview of the findings.

\section{Summary of Findings}

To identify the independent variables that influenced persistence to the second year of college, four models were created. The first model measured the dependent variable, persistence to the second year of college, in relation to the eight independent variables of SES, family income, high school GPA, gender, highest degree expected, financial aid, academic engagement, and social engagement. The second model measured the dependent variable in relation to the eight stated independent variables plus college generation. The third model added parental involvement to the nine stated independent variables, and the last model examined all of the variables plus college generation and parent involvement interaction. Parental involvement was anticipated as an important persistence factor in this dissertation. It was also anticipated that college generation status would be also be a significant predictor of persistence to the second year of college.

\section{Model 1: Eight Core Independent Variables}

The first logistic regression model sought to examine the extent to which the eight core independent variables of SES, family income, high school GPA, gender, highest degree expected, financial aid, academic engagement, and social engagement predicted persistence to the second year of college. The results of the dissertation indicate that high school grade point average (GPA), highest degree expected, and academic engagement 
predicted persistence to the second year of college for this population of students.

\section{Model 2: Core Independent Variables Plus College Generation}

The second logistic regression model sought to determine whether the addition of college generation to the eight core independent variables would show an influence on persistence to the second year of college. Results indicated that there was no statistically significant relationship between college generation and predicting persistence of the students in this dissertation.

\section{Model 3: Nine Independent Variables Plus Parental Involvement}

The third model generated from the data built upon the prior two logistic regression models, this time adding the independent variable of parental involvement. The findings indicate that parental involvement as conceptualized in the model was not significant in predicting the persistence of students to the second year, perhaps because the parental involvement variable concentrated on questions of an academic nature. Moreover, the parental involvement variable was not measured by the interactions and conversations that Hispanic parents have with their children about the importance of pursuing a higher education. This type of parental involvement is exemplified by a father showing his daughter or son the calluses on his hands and stressing the need to go to college to avoid the physical demands of working as a construction worker.

\section{Model 4: Ten Independent Variables Plus College Generation X Parental Involvement}

The final regression model sought to determine whether the interaction of college generation and parental involvement, added to the previously mentioned independent variables, might influence the model. Results revealed that the addition of the college 
generation and parental involvement interaction term statistically improved model fit and was associated with persistence to the second year of college. Additional examination of the data revealed that among students who had low parental involvement, non-first generation college students were more likely to persist to the second year of college than first-generation college students. There was not a statistically significant association between college generation and persistence to the second year of college for those reporting high parental involvement. Additional analysis of the relationship between parental involvement and persistence to the second year of college based on college generation showed no statistically significant association for first-generation college students or for non-first generation college students.

\section{Limitations}

A variety of limitations naturally constrain the conclusions drawn from this dissertation. First, the parental involvement variable was limited to the answers provided by parents and students in the survey instruments included in the Education Longitudinal Study of 2002 (ELS: 2002) that was designed by the United States Department of Education. The parental involvement data measured the frequency of the involvement rather than the quality of the involvement. The data did not capture the important interactions and conversations that Hispanic parents have with their children about the value of higher education. Second, this dissertation did not include the Hispanic ELS: 2002 participants who did not attend college. As with any research, it is important to recognize the limitations associated with the research design and analysis, but they should not diminish the value of the research. With these limitations noted, the following section considers the conclusions and implications stemming from this dissertation. 


\section{Conclusions and Implications}

\section{Eight Core Independent Variables}

Understanding if the eight core independent variables predicted persistence to the second year of college is important to researchers and practitioners because these variables have been found to be significant predictors of persistence in previous studies. This dissertation confirms previous findings on three of the core independent variables. First, the results of this dissertation are in line with previous studies that have found the importance of high school grade point average in predicting the persistence of students (Hoffman \& Lowitzki, 2005; Lotkowski et al., 2004). Second, the findings of this dissertation also affirm the earlier work of Tinto (1987) and Bean (1980) who found that academic engagement through the frequency of interaction with academic advisors and faculty members is significant. Third, the significance of the student expectation of highest degree earned is similar to Perna's (2000) finding that aspiring to an advanced degree has a positive influence on college enrollment rates for Hispanic students. This result emphasizes the need for schools and parents to be involved at an earlier age to build the appropriate educational expectations and preparation of students.

However, it was unexpected that five of the eight core independent variables were found not be significant predictors of persistence. The findings on socio-economic status and family income are not consistent with the literature (McCarron \& Inkelas, 2006; Perna \& Titus, 2005; Trusty, 1998). While gender was not a significant predictor in this dissertation, there are several studies that have found gender to be an important persistence factor (Pascarella \& Terenzini, 1980, 1983; Stage, 1988; Stage \& Hossler, 1989) and significant in differentiating between students who earn a certificate and those 
who earn a degree (Sciarra \& Whitson, 2007). In addition, the findings of this dissertation do not reflect previous studies that have demonstrated that financial aid programs increase persistence. Rodriguez et al. (2000) operationalized financial aid variables in a similar manner and found them to be significant predictors of persistence. The difference between the results of this dissertation and the literature may be attributed to the composition of the financial aid variable. The financial aid variable included student loans, grants and scholarships, and college work study. The inclusion of student loans may have impacted the results because many Hispanic students are reluctant to take out loans. Moreover, the finding that social engagement was not a significant predictor was unforeseen considering the extensive body of literature that has emphasized that social integration and student participation in extra-curricular activities is an important contributor to student college retention (Astin, 1999; Tinto, 1987). The difference may be explained by how Hispanic students defined extra-curricular activities. They may not have considered their involvement in an honors business fraternity or volunteering as a peer mentor as extra-curricular activities.

\section{College Generation}

A great deal of higher education research (Ishitani, 2006; Lee et al., 2004;

Pascarella et al., 2004) has focused on the experiences of first-generation college students and the unique needs of this population. The results of this dissertation contribute to the existing literature by examining how college generation is correlated with the persistence of first-generation Hispanic Millennial college students in particular. The result of this dissertation contradicts the research that identifies first-generation status as a having a negative relationship with the persistence of Hispanic college students. This finding has 
implications for higher education professionals who are trying to address the needs of first-generation students and can help inform them that the differences between firstgeneration and non-first-generation students are not as substantial when you control for socioeconomic status, family income, high school grade point average, gender, highest degree expected, financial aid, social engagement, and academic engagement.

\section{Parental Involvement}

Parental involvement was anticipated as an important persistence factor in this dissertation based on the foundational work of Coleman (1988) who conceptualized parental involvement as a form of social capital that provides individuals with access to resources that may facilitate college enrollment. Coleman's study (1988) and the work of several others (Perna \& Titus, 2005; McCarron \& Inkelas, 2006; Sciarra \& Whitson, 2007) who have emphasized the effect of parental involvement on persistence is contradicted by the results of this dissertation, which show that parental involvement is not a significant predictor of persistence for this population.

Perna and Titus (2005) demonstrated that the odds of enrolling in college relative to not enrolling increased with the frequency with which the parent discussed with the student education-related topics similar to the topics found in the parental involvement variable used in this dissertation. The results of this dissertation indicate that the social capital effect of parental involvement may wear off as students progress through their first year of college and have less contact with from their parents. McCarron \& Inkelas (2006) conducted a study whose purpose was to determine if parental involvement was a significant predictor of college degree attainment. Their study demonstrated that parental involvement was the best predictor of college degree attainment for non-first-generation 
students, but it was not the main predictor for first-generation students. For both groups, parental involvement was strong in explaining variance. Their study focused on homebased involvement and did not examine school-based involvement such as parents taking an active role in interacting with teachers and counselors. Therefore, this dissertation used additional factors to operationalize parental involvement to see if it would yield a different result for first-generation students. The inclusion of several school based involvement factors did not make the parental involvement variable a significant predictor of retention. It is difficult to understand why parental involvement as operationalized in this dissertation was not a significant predictor of retention for either first-generation or non-first-generation Hispanic millennial college students.

The results of this dissertation have direct implications for primary and secondary educators and counselors who want to increase the educational expectations of their students. While this dissertation did not demonstrate that parental involvement is a significant predictor of retention for this population, other studies have demonstrated that student expectations of educational attainment can be raised by their parents. Therefore, primary and secondary level educational programming that focuses on raising the awareness of parents and their role in the educational expectations of the children are necessary and can have an impact on the retention of those students who attend college.

\section{College Generation and Parental Involvement}

The influence of college generation and parental involvement was examined in order to find if their interaction was a significant predictor of persistence to the second year of college. The interaction between these two variables was important to test because previous research indicates that first-generation students lack the necessary 
social capital provided by parental involvement. The results indicated that even higher levels of parental involvement did not increase persistence for either first-generation or non-first-generation students. This information can be useful for researchers seeking to understand the relationship between college generation and parental involvement for Hispanic first-generation and non-first-generation college students. Again, how parental involvement is conceptualized in future studies may make a significant difference in the results.

\section{Recommendations for Research}

Several recommendations for future research in the area of Hispanic college student persistence can be suggested. Specifically, there are five recommendations that might be considered as a natural extension to this dissertation, and hold the potential to further advance findings in Hispanic student persistence research.

\section{Conducting Research on the Next College Generation}

The analysis in this dissertation can be repeated in 5 years to capture changes in generational trends and academic philosophies toward first-generation college students. A future study that focuses on the unique characteristics of the next generation of college students may have different results than with the Millennial college students in this dissertation. Students who are part of the Millennial generation have seven core traits: special, sheltered, confident, team-oriented, conventional, pressured, and achieving (Howe and Strauss 2007). In addition, the current emphasis placed on the needs of firstgeneration students in the literature and by higher education institutions may also have an impact on the results of future persistence studies. 


\section{Conducting Research on Educational Attainment}

A study could be conducted in 2014 after the final data is made available on students in the Education Longitudinal Study of 2002 cohort. The final data will provide information on whether students earned a degree four years after the students graduated from high school. The future study would examine if parental involvement was a significant predictor of degree attainment for Hispanic Millennial college students. The study would be similar to the study McCarron and Inkelas (2006) conducted using the NELS data. McCarron's conclusion was that parental involvement was quite strong in explaining variance and supports prior research on the importance of parental involvement.

\section{Conceptualization of Parental Involvement}

Based on previous studies, it was anticipated that the parental involvement would have been a significant predictor of student persistence in this dissertation. The results of this dissertation which indicate otherwise, may be attributed to the fact that most of the survey questions used to operationalize the parental involvement variable were related to academic involvement by parents and there were limitations in the database to the questions related to social capital. The current study could be replicated by examining the effect of a parental involvement composed of different survey questions from the ELS:2002. Future studies can use questions that concentrate more on how parents use non-academic related factors to build their child's college expectations and aspirations. Moreover, future studies can create a parental involvement variable that measures quality of interaction rather than frequency of interaction. 


\section{Conducting Research with Hispanic Serving Institutions}

This dissertation can be repeated using only Hispanic students who attend Hispanic Serving Institutions. Title V of the Higher Education Act recognizes colleges and universities whose full-time equivalent undergraduate enrollment is at least $25 \%$ Hispanic as a Hispanic Serving Institution. Research shows that Hispanic students who attend Hispanic Serving Institutions have higher persistence and graduation rates than those Hispanic students who attend non-Hispanic Serving Institutions (American Enterprise Institute, 2010).

\section{Conducting Research on Regional Differences}

A study can be conducted focusing on the regional differences between Hispanic college students. While $68 \%$ of Hispanics are of Mexican origin and primarily concentrated in the South and West regions of the United States, each region of the United States has concentrations of Hispanic students of different origins. The Northeast region has Hispanics primarily of Puerto Rican and Dominican descent and the Southeast region has mostly Hispanics of Cuban origin (U.S. Census Bureau, 2010). The study would compare Hispanic students grouped by region to determine if they share any of the same significant predictors of persistence.

Beyond research, the application of this dissertation also shows potential for improving practices in primary and secondary education as well as in the roles of faculty members and student support professionals in higher education. The final section of this dissertation provides recommendations for improving practice based on the results of the research. 


\section{Recommendations for Practice}

In this section, recommendations for practice are presented, drawing from the findings in this dissertation and the literature. The recommendations are addressed to the key stakeholders who contribute to the educational lives of Hispanic students.

\section{Primary and Secondary Educators and Counselors}

The highest degree expected by the population studied in this dissertation was a significant predictor of persistence to the second year of college. Therefore, setting and maintaining high career and educational expectations at an early age is an important factor to consider for primary and secondary level educators and counselors. Setting these high career and educational expectations has to start at the primary school level with creating a culture of college. A culture of college is where all students have the expectation that they will go to college. The culture in schools has to shift from attempting to hang on to students until they graduate to providing a challenging environment that supports the transition from childhood to adulthood (McClafferty, McDonough, \& Nunez, 2002). Three things are necessary to create a culture of college: 1) commitment from school leadership, 2) counselors and teachers are partners in preparing students for college, and 3) all school personnel provide a consistent message to students that support their quest for the college experience. Regardless of socioeconomic status or whether their parents attended college, Hispanic students need to visualize themselves going to college. School systems that create a culture of college showcase former students who are attending college, teachers who talk about college all the time to all the students, and counselors who support them in the college search and the application process (Camblin, Gullatt, \& Klopott, 2003). 
Schools should seek to actively engage Hispanic parents in developing their expectations for their children since parental expectations and involvement are two of the most influential predictors of students' expectations (Wells et al., 2011). Primary and secondary school systems need to increase the number of parent education programs that inform parents and get them more involved in their child's education. Chrispeels and Rivero (2001) found that after participating in this type of education program, Hispanic parents reported dramatic changes in their parenting behaviors, such as praising their child and establishing rules and limits to television viewing. College expectations were directly affected by knowledge, parenting practices, and self-efficacy. These results show that a parent education program can have a significant effect on motivators of parent involvement at both elementary and secondary levels by increasing parents' knowledge of how to be involved (Chrispeels \& Gonz, 2004).

\section{Academic Advisors}

This dissertation has demonstrated that more interaction with academic advisors is important to the persistence of first-generation Hispanic Millennial students. Therefore, it is critical that academic advisors find more effective ways to reach out to Hispanic students and increase the frequency of their interactions. According to Torres (2006), the traditional approach in which students are expected to know where to seek advising help does not necessarily work for first-generation Hispanic college students. They may be reluctant to automatically trust authority figures because of their previous negative encounters with people in authority or lack of understanding for identifying authorities. Trust must be earned by any authority figure before a first-generation Hispanic student will see that person as helpful. Unfortunately, many Hispanic students rely on peers and 
printed materials and will only seek out advisors if they reach a moment of academic crisis.

Therefore, colleges and universities need to implement more holistic and intrusive forms of academic advising. Advisors should provide holistic academic advising that attempts to understand nonacademic challenges faced by Hispanic students that might impact their academic experiences. Understanding nonacademic issues can enable advisors to more effectively understand the issues that their students face and when they should refer students to other offices on campus. Advisors should be aware of the cultural factors that are significant to their Hispanic advisees such as the importance placed on the family. As a result, advisors need to have cultural awareness training and should consider involving Hispanic families in the advising process (Museus \& Ravello, 2010).

In addition, academic advising offices should try to make their delivery of services more proactive and intrusive. Beyond their typical academic advising duties, advisors should consider proactively introducing or accompanying students to activities, events, and networks that will expose them to faculty members and peers with similar interests. Advisors need to seek out the Hispanic student population and not expect them to come on their own. Advisors should also consider how to fully incorporate intrusive advising practices into their work, including making regular phone and electronic contact throughout the term and implementing monitoring and early intervention systems that can prevent students from falling through the proverbial cracks in the system (Museus \& Ravello, 2010).

\section{College Faculty}

The quality of student-faculty interactions is positively correlated with student satisfaction, the college experience, academic achievement, personal and intellectual 
development, and persistence (Pascarella \& Terenzini, 2005). Students are more likely to interact with faculty members outside the classroom when faculty members show openness and flexibility towards the student, when they seem interested in the student's personal life, when they are friendly and caring, and when they give cues about their approachability. Faculty members display these behaviors when they are eager to learn students' names, stress that office hours were important, when they had a sense of humor, were entertaining and passionate about teaching, and when they recognized students on campus. Students are interested in interacting with faculty who display the human qualities of care and passion (Vianden, 2009).

\section{Library Administrators}

The findings of this dissertation indicate that library usage by Hispanic college students is a significant predictor of their persistence to the second year of college. While there are no other studies that affirm these findings specifically for Hispanic college students, Blackburn (2010) asserts that the academic library has a significant role in maintaining and increasing student retention. In addition, Matthews (2007) reports in his study that those students who used campus support services such as libraries did better academically than their counterparts.

Therefore, it is important that Hispanic college students be introduced to the library as early as possible. Simply visiting the library with a first-year orientation class can help alleviate some student reservations about using the library. Colleges and universities need to go beyond the traditional handout with the library hours or a scavenger hunt to the library reference desk. They need to fully utilize the power of a first-year orientation class to make students more aware of their campus library. When 
designing first-year orientation classes, librarians should be consulted to make sure the curriculum of these classes includes the skills necessary for students to effectively navigate online and in-person library services (Gardner \& Hardesty, 2004). For Hispanic students to see the library as a place to study, libraries have to change their image from academic archive to attractive study halls. Library administrators report that students are looking for a place to meet other students and work on group projects. The library has to be a welcoming social environment where students can experience the company of other students (Waxman et al., 2007).

\section{Summary}

This dissertation used social capital theory as a theoretical framework for analyzing and gaining a greater understanding of the factors that contribute to the persistence of first-generation Hispanic college Millennial students. This dissertation attempted to answer the following research question: What is the relationship between parental involvement and college generation status with the persistence of Hispanic Millennial college students? The research question assumed several variables, socioeconomic status (SES), family income, high school grade point average, gender, highest degree ever expected, financial aid, social engagement, academic engagement, college generation (first/non-first generation), and parental involvement. Based on the literature, it was expected that parental involvement would be a strong predictor of student retention because of the assertion made by Howe and Strauss (2000) that Millennial students have stronger relationships with their parents.

This dissertation used data collected from 1179 Hispanic students who participated in the Education Longitudinal Study of 2002 (ELS: 2002). Logistic 
regression analysis was used in this dissertation to examine the relationship between the dependent variable, which is student persistence to the second year, and the 10 independent variables stated above. The results of this dissertation indicate that while parental involvement was not a significant predictor of persistence to the second year of college for Hispanic college Millennial students, it did find that high school grade point average, highest degree expected, and academic engagement as operationalized in this dissertation were significant predictors.

While there are several studies that had focused on the retention of firstgeneration students and Hispanic students in general (Hernandez, 2000; Pascarella, 2004; Perna, 2000; Somers \& Cofers, 2004), this dissertation is the first retention study that focused on Millennial students. The quantitative results from this dissertation serve as a starting point for better understanding whether parental involvement is a predictor of college persistence of Hispanic Millennial college students. While the results did not indicate that parental involvement was a significant factor in persistence to the second year of college, it is important that those involved in the education of Hispanic students do not dismiss the role of parental involvement because parental involvement can be defined in many ways that are different from the definition used in this dissertation. Educators at all levels need to engage Hispanic parents and make them aware of the higher education opportunities available to Hispanic students. There has to be a collaborative effort between educators and parents to increase the educational goals and degree expectations of all Hispanic students. 


\section{List of References}

American Enterprise Institute. (2010). Rising to the challenge: Hispanic college graduation rates as a national priority. Washington, DC: Author.

Ary, D., Jacobs, L.C., \& Razavieh, A. (2002). Introduction to Research in Education. Belmont, CA: Wadworth/Thomson Learning.

Astin, A. W. (1999). Student involvement: A developmental theory for higher education. Journal of College Student Development, 40(5), 518-529.

Bank, B. J., Slavings, R. L., \& Biddle, B.J. (1990). Effects of peer, faculty, and parental influences on students' persistence. Sociology of Education, 63, 208-225.

Bean, J. P. (1980). Dropouts and turnover: The synthesis and test of a causal model of student attrition. Research in Higher Education, 12(2), 155-187.

Berger, J. B. (2000). Optimizing capital, social production, and undergraduate persistence. In J.M Braxton (Ed.), Reworking the student departure puzzle, 95124. Nashville: Vanderbilt University Press.

Blackburn, H. (2010). Shhh! No talking about retention in the library! Education Libraries, 33(1), 24-30.

Cabrera, A. F., Castaneda, M. B., Nora, A., \& Hengstler, D. (1992). The convergence between two theories of college persistence. Journal of Higher Education, 63(2). 143-164.

Cabrera, A. F., Nora, A., \& Castaneda, M. B. (1993). College persistence: Structural equations modeling test of an integrated model of student retention. Journal of Higher Education, 64(2), 123-139.

Camblin, S. J., Gullatt, Y., \& Klopott, S. (2003). Strategies for success: Six Stories of Increasing college Access. A white paper for the Pathways to College Network. Boston, MA: Pathways to College Network.

Coleman, J. S. (1988). Social capital in the creation of human capital. American Journal of Sociology, 94, 95-120.

Coomes, M.D. \& DeBard, R. (2004). A generational approach to understanding students. New Directions for Student Services, 106, 5-16. 
Chrispeels, J. H., \& Gonz, M. (2004). Do educational programs increase parents' practices at home?: Factors influencing Latino parent involvement (Family Involvement Research Digests). Retrieved November 23, 2011, from http://www.hfrp.org/publications-resources/publications-series/familyinvolvement-research-digests/do-educational-programs-increase-parentspractices-at-home-factors-influencing-latino-parent-involvement

Chrispeels, J. H., \& Rivero, E. (2001). Engaging Latino families for student success: How parent education can reshape parents' sense of place in the education of their children. Peabody Journal of Education, 76(2), 119-169.

DeBard, R. (2004). Millennials coming to college. New Directions for Student Services, $106,33-45$.

Epstein, J. L. (1990). School and family connections: Theory, research, and implications for integrating sociologies of education and family. Marriage and Family Review, 15(1), 99-126.

Gardner, J. N. \& Hardesty, L. (2004). The reform movement for the first-year experience: What is the role of librarians? Library Issues, 24(5). Retrieved January 8, 2012 from www.libraryissues.com

Glynn, J. G., Sauer, P. L., \& Miller, T. E. (2003). Signaling student retention with pre-matriculation data. NASPA Journal, 41(1), 41-67.

Gonzalez, J. (2010). Low Hispanic graduation rates threaten Obama's college-attainment goal. The Chronicle of Higher Education. Retrieved from http://chronicle.com/article/Low-Hispanic-Graduation-Rat/64710/

Harrell, P. E., \& Forney, W. S. (2003). Ready or not, here we come: Retaining Hispanic and first-generation students in postsecondary education. Community College Journal of Research and Practice, 27, 147-156.

Hernandez, J.C. (2000). Understanding the retention of Latino college students. Journal of College Student Development, 41(6), 575-588.

Hernandez, J. C.,, \& Lopez, M. C. (2004). Leaking pipeline: Issues impacting Latino/a college student retention. Journal of College Student Retention, 6(1), 37-60.

Hinkle, D. E., Wiersma, W., \& Jurs, S. G. (2003). Applied Statistics for the Behavioral Sciences. Boston: Houghton Mifflin.

Hoffman, J. L. \& Lowitzki, K. E. (2005). Predicting college success with high school grades and test scores: Limitations for minority students. The Review of Higher Education, 28(4), 455-474. 
Hoover-Dempsey, K. V., Sandler, H. M., Green, C. L., \& Walker, J. T. (2007).

Parents' motivations for involvement in children's education: An empirical test of a theoretical model of parental involvement. Journal of Educational Psychology, 99(3), 532-544.

Hosmer, D. W., \& Lemeshow, S. (1989). Applied Logistic Regression. New York: Wiley.

Howe, N. \& Strauss, W. (2000). Millennials Rising: The next great generation. New York: Vintage Books.

Howe, N \& Strauss, W. (2007). Millennials going to college: Strategies for a new generation on campus. Great Falls: Lifecourse Associates.

Ishitani, T. T. (2006). Studying attrition and degree completion behavior among firstgeneration college students in the United States. The Journal of Higher Education, 77(5), 861-885.

Jaccard, J. (2001). Interaction effects in logistic regression. Albany, NY: State University of New York.

Kim, D. H., \& Schneider, B. (2005). Social capital in action: Alignment of parental support in adolescents' transition to postsecondary education. Social Forces, 84(2), 181-206.

Lee, J. J., Sax, L. J., Kim, K. A., \& Hagedorn, L. S. (2004). Understanding students' parental education beyond first-generation status. Community College Review, 32(1), 1-20.

LeSure-Lester, G. E. (2003). Effects of coping styles on college persistence decisions among Latino students in two year colleges. Journal of College Student Retention, 5(1), 11-22.

Lohfink, M. M., \& Paulsen, M. B. (2005). Comparing the determinants of persistence for first generation and continuing-generation students. Journal of College Student Development, 46(4), 409-428.

Longerbeam, S. D., Sedlacek, W. E., \& Alatorre, H. M. (2004). In their own voices: Latino student retention. NASPA Journal, 41(3), 538-50.

Lotkowski, V. A., Robbins, S.B., \& Noeth, R. J. (2004). The role of academic and nonacademic factors in improving college retention. ACT. Retrieved January 8, 2012 from www.act.org/path/policy/pdf/college_retention.pdf.

Madgett, P. J. \& Bélanger, C. H. (2008). First university experience and student retention factors. Canadian Journal of Higher Education, 38(3), 77-96. 
Matthews, J. R. (2007). The evaluation and measurement of library services. Westport: Libraries Unlimited.

McCarron, G. P., \& Inkelas, K. K. (2006). The gap between educational aspirations and attainment for first-generation college students and the role of parental involvement. Journal of College Student Development, 47(5), 534-549.

McClafferty, K., McDonough, P., \& Nunez, A. (2002, April). What is college culture? Facilitating college preparation through organizational change. Paper presented at the annual conference of the American Educational Research Association, New Orleans, LA.

McNeal, R. B. (1999). Parental involvement as social capital: Differential effectiveness on science, achievement, truancy, and dropping out. Social Forces, 78(1), 117144.

Museus, S. D., \& Ravello, J. N. (2010). Characteristics of academic advising that contribute to racial and ethnic minority student success at predominantly white institutions. NACADA Journal, 30(1), 47-58.

National Center for Education Statistics (2008). Retrieved March 5, 2008, from http://nces.ed.gov/surveys/els2002.

National Center for Education Statistics. (2007). Status and Trends in the Education of Racial and Ethnic Minorities (NCES 2007-039). Washington, DC.

Newman, I., \& Newman, C. (1994). Conceptual statistics for beginners. Lanham: University Press of America.

Pascarella, E. T., \& Chapman, D. W. (1983). Validation of a theoretical model of college withdrawal: Interaction effects in a multi-institutional sample. Research in Higher Education, 19, 25-48.

Pascarella, E. T., \& Terenzini, P. (1980). Predicting freshman persistence and voluntary dropout decisions from a theoretical model. Journal of Higher Education, 51(1), 60-75.

Pascarella, E. T., \& Terenzini, P. (1983). Path analytic validation of Tinto's model. Journal of Educational Psychology, 75(2), 215-226.

Pascarella, E. T., \& Terenzini, P. T. (2005). How college affects students: A third decade of research. San Francisco: Jossey-Bass. 
Pascarella, E. T., Wolniak, G. C., Pierson, C. T. \& Terenzini, P. T. (2004). Firstgeneration college students: Additional evidence on college experiences and outcomes. The Journal of Higher Education, 75(3), 249-284.

Perna, L. W. (2000). Differences in the decision to attend college among African Americans, Hispanics, and Whites. The Journal of Higher Education, 71(2), 117141.

Perna, L. W., \& Titus, M. A. (2005). The relationship between parental involvement as social capital and college enrollment: An examination of racial/ethnic group differences. The Journal of Higher Education, 76(5), 485-518.

Pew Hispanic Center. (2009). Latinos and education: Explaining the attainment gap. Washington, DC.

Pew Research Center. (2010). Millennials: A portrait of generation next. Washington, DC.

Rodriguez, A. L., Guido-DiBrito, F., Torres, V., \& Talbot, D. (2000). Latina college students: Issues and challenges for the $21^{\text {st }}$ century. NASPA Journal, 37(3), 511527.

Rowan-Kenyon, H.T., Bell, A.D., \& Perna, L. W. (2008). Contextual influences on parental involvement in college going: variations by socioeconomic class. The Journal of Higher Education, 79(5), 564-586.

Sandefur, G. D., Meier, A. M., \& Campbell, M. E. (2006). Family resources, social capital, and college attendance. Social Science Research, 35, 525-553.

Saunders, M., \& Serna, I. (2004). Making college happen: The college experience of first-generation Latino students. Journal of Hispanic Higher Education, 3(2), $146-163$.

Sax, L. J. (2003). Our incoming students: What are they like? About Campus, 8(3), $15-20$

Sciarra, D. T., \& Whitson, M. L. (2007). Predictive factors in postsecondary educational attainment among Latinos. Professional School Counseling, 10(3), 307-316.

Solis, E. (1995). Regression and path analysis models of Hispanic community college students' intent to persist. Community College Review, 23(3), 3-15.

Somers, P., Woodhouse, S., \& Cofer, J. (2004). Pushing the boulder uphill: The persistence of first-generation college students. NASPA, 41(3), 418-435. 
Stage, F. K. (1988). University attrition: LISREL with logistic regression for the persistence criterion. Research in Higher Education, 29 (4), 343-357.

Stage, F., \& Hossler, D. (1989). Differences in family influences on college attendance plans for male and female ninth graders. Research in Higher Education, 30(3), 301-315.

Stanton-Salazar, R. D. (1997). A Social capital framework for understanding the socialization of racial minority children and youths. Harvard Educational Review, 67(1), 1-38.

Tabachnick, B. G., \& Fidell, L. S. (2007). Using multivariate statistics (5th ed.). Boston: Allyn and Bacon.

Tinto, V. (1987). Leaving College: Rethinking the Causes and Cures of Student Attrition. Chicago: University of Chicago Press.

Torres, V., Reiser, A., LePeau, L., Davis, L., Ruder, J. (2006). A model of firstgeneration Latino/a college students' approach to seeking academic information. NACADA Journal, 26 (2), 65-70.

Trusty, J. (1998). Family influences on educational expectations of late adolescents. Journal of Educational Research, 91, 260-270.

United States Census Bureau (2010). Retrieved February14, 2012, from http://www.census.gov/population/www/socdemo/hispanic/cps2010.html

United States Department of Commerce. U.S. Census Bureau. (2009). Census Bureau Releases Data Showing Relationship Between Education and Earnings by Tom Edwards. Washington, DC: U.S. Census Bureau.

United States Department of Education, National Center for Education Statistics. (2004). Education Longitudinal Study of 2002: Base Year Data File User's Manual, by Steven J. Ingels, Daniel J. Pratt, James E. Rogers, Peter H. Siegel, and Ellen S. Stutts. Washington, DC: National Center for Education Statistics.

Vianden, J. (2009). Exploring college men's perceptions about interacting with faculty beyond the classroom. The College Student Affairs Journal, 27(2), 224-241.

Waxman, L., Clemons, S., Banning, J., \& McKelfresh, D. (2007). The library as place: Providing students with opportunities for socialization, relaxation, and restoration. New Library World, 108(9/10), 424-434. 
Wells, R. S., Seifert, T. A., Padgett, R. D., Park, S., \& Umbach, P. D. (2011). Why do more women than men want to earn a four-year degree? Exploring the effects of gender, social Origin, and social capital on educational expectations. The Journal of Higher Education, 82(1), 1-32.

Yan, W. (1999). Successful African American students: The role of parental involvement. Journal of Negro Education, 68(1), 5-22.

Zurita, M. (2004). Stopping out and persisting: experiences of Latino undergraduates. Journal of College Student Retention, 6(3), 301-324. 
VITA

ANTHONY CRUZ

\section{EDUCATION:}

Florida International University, Miami, FL

Doctoral Candidate in Higher Education Administration, 2012

Florida State University, Tallahassee, Florida

Master in Public Administration, 1993

Florida International University, Miami, Florida

Bachelor of Arts in Political Science, 1991

PROFESSIONAL EXPERIENCE:

CINCINNATI STATE TECHNICAL \& COMMUNITY COLLEGE, Ohio

Dean of Enrollment and Student Development (1/09-Present)

BROWARD COLLEGE, Pembroke Pines, Florida

Associate Dean of Student Affairs (2/07-1/09)

FLORIDA INTERNATIONAL UNIVERSITY, Miami, Florida

Director of Student Services (6/04-1/07)

FLORIDA INTERNATIONAL UNIVERSITY, Miami, Florida Program Director (11/02-5/04)

KAPLAN UNIVERSITY, Boca Raton, Florida

Director of Academic Advising (12/01 - 11/02)

CHARLES SCHWAB \& CO., Miami, Florida

Investment Specialist $(2 / 00-12 / 01)$

PRUDENTIAL FINANCIAL PLANNING SERVICES, Florida Financial Planner (7/98 - 2/00)

FLORIDA INTERNATIONAL UNIVERSITY, Miami, Florida Assistant Dean for Student Services/Instructor (10/95 - 7/98)

FLORIDA INTERNATIONAL UNIVERSITY, Miami, Florida Coordinator of Student Services/Instructor (4/95 - 10/95) 
FLORIDA INTERNATIONAL UNIVERSITY, Miami, Florida

Assistant Director of Admissions (7/93 - 3/95)

PROFESIONAL AFFILIATIONS:

NASPA

Member of Student Affairs Administrators in Higher Education

NACADA

Member of the National Academic Advising Association

TEACHING EXPERIENCE:

Florida International University, Miami, Florida

Introduction to Public Administration. Units included organizational behavior, intergovernmental relations, personnel management, budgeting, regulatory policy, and ethics.

Policy Development and Its Implementation. Units included the policy development process, models of politics, American Federalism, current economic and social program policy.

Miami Dade College, Miami, Florida

College Survival Skills. Units included time management, career planning, study techniques, and goal setting. 